No 4078

Studia nad Autorytaryzmem i Totalitaryzmem 43, nr 4 Wrocław 2021

https://doi.org/10.19195/2300-7249.43.4.41

\author{
EMIL W. PŁYWACZEWSKI \\ ORCID: 0000-0002-4191-981X
}

Uniwersytet w Białymstoku

e.plywaczewski@uwb.edu.pl

\title{
Zapobieganie przestępczości i sprawiedliwość karna z perspektywy Kongresów Organizacji Narodów Zjednoczonych
}

Słowa kluczowe: Narody Zjednoczone, kongresy Organizacji Narodów Zjednoczonych, zapobieganie przestępczości i sprawiedliwość karna (postępowanie z przestępcami), standardy i normy Narodów Zjednoczonych w zakresie zapobiegania przestępczości i sprawiedliwości karnej, deklaracje kongresów ONZ.

\section{CRIME PREVENTION AND CRIMINAL JUSTICE FROM THE PERSPECTIVE OF UNITED NATIONS CONGRESSES}

\begin{abstract}
For over 65 years, the United Nations has held congresses aimed at strengthening international cooperation against expanding crime. The First Congress on the Prevention of Crime and Treatment of Offenders took place in Geneva in 1955. Sixty-six years later, in 2021, this tradition continued, postponed by the Covid-19 epidemic, as the Fourteenth United Nations Congress on Crime Prevention and Criminal Justice took place in the former capital of Japan - Kyoto. The aim of the paper is to present the most important achievements of all 14 congresses, especially focusing on the development of UN standards and norms in crime prevention and criminal justice. The author also presents the history of the participation and activities of Polish participants of the Congresses (official delegates and individual experts) in the years 1960-2021. The general conclusion is that the institution of the UN Crime Congresses is a major high-level forum to steer the development of the rule of law, to promote global security and good governance, and to improve the response to crime.
\end{abstract}

Keywords: United Nations, UN congresses, crime prevention and criminal justice (treatment of fffenders), UN standards and norms in crime prevention and criminal justice, declarations of $U N$ congresses. 


\section{Uwagi ogólne}

W dniu 26 czerwca 1945 roku przedstawiciele 50 państw podpisali się w San Francisco pod aktem tworzącym Organizację Narodów Zjednoczonych. Z perspektywy tak zwanego międzynarodowego prawa karnego był to niewątpliwie okres szczególny. Społeczność międzynarodowa stanęła bowiem przed koniecznością wypracowania rozwiązań prawnych stanowiących reakcję na okrucieństwa drugiej wojny światowej. Sformułowano wówczas reguły prawa międzynarodowego odnoszące się do sfery karnej. Przybrały one postać Porozumienia międzynarodowego w przedmiocie ścigania i karania głównych przestępców wojennych Osi Europejskiej z dnia 8 lipca 1945 roku (tak zwane porozumienie londyńskie) ${ }^{1}$, stanowiącego załącznik do tego porozumienia statutu Międzynarodowego Trybunału Wojskowego w Norymberdze oraz wyroku tegoż Trybunału Norymberskiego z 30 września - 1 października 1946 roku. Owe zasady (reguły) prawa międzynarodowego zostały potwierdzone w jednomyślnej rezolucji 95 (I) Zgromadzenia Ogólnego Narodów Zjednoczonych z dnia 11 lipca 1946 roku. Kolejne dokumenty wypracowane przez Narody Zjednoczone, w postaci ogłoszonej przez Zgromadzenie Ogólne NZ Powszechnej Deklaracji Praw Człowieka z 10 grudnia 1948 roku oraz paktów praw obywatelskich i politycznych z 16 grudnia 1966 roku budują dzisiaj fundament współczesnej ochrony praw człowieka.

Organizacja Narodów Zjednoczonych, obok wielu zadań politycznych (głównym organem politycznym ONZ jest Rada Bezpieczeństwa) ${ }^{2}$, ekonomicznych i społecznych zajmuje się także problematyką zwalczania i ograniczania przestępczości i jest organizatorem kongresów temu poświęconych ${ }^{3}$. Ich tematy są często logicznym następstwem zagadnień poruszanych na poprzednich spotkaniach, co stanowi o systematycznym rozszerzaniu zakresu zainteresowań i kreowaniu nowych nurtów celem wypracowania określonych standardów oraz zbliżenia poszczególnych systemów prawnych i praktyki w kierunku skuteczniejszej ochrony praw człowieka, także w odniesieniu do występujących w różnych częściach świata zjawisk totalitaryzmu i ekstremizmu. W literaturze wskazuje się

1 Dz.U. z 1947 r. Nr 63, poz. 367.

2 Szerzej zob. B. Krzan, Kompetencje Rady Bezpieczeństwa ONZ w międzynarodowym sqdownictwie karnym, Toruń 2007.

${ }^{3}$ Zadanie to zostało przyjęte rezolucją Zgromadzenia Ogólnego ONZ 415 (V) uchwaloną 1 grudnia 1950 roku — od Międzynarodowej Komisji Karnej i Penitencjarnej (IPPC — dawniej Międzynarodowej Komisji do spraw Więzień) - najstarszej organizacji międzynarodowej tego typu działającej od 1872 roku w Londynie. Światowe kongresy zwoływane przez IPPC poświęcone były początkowo problematyce penitencjarnej, a później także profilaktycznej, kryminologicznej i prawa karnego. W miejsce IPPC utworzono Międzynarodową Fundację Karną i Penitencjarną (IPPF) z siedzibą w Bernie (Szwajcaria). Szerzej na ten temat — zob. J. Górny, Rola międzynarodowych kongresów penitencjarnych w rozwoju teorii i praktyki wykonania kary, Warszawa 1980; J. Węgrzyn, Struktury Organizacji Narodów Zjednoczonych zajmujące się problematyka przestępczości, „Nowe Prawo” 1991, nr 4-6, s. 66 n. 
na interdyscyplinarność, wielopłaszczyznowość i dynamikę polityki kryminalnej ONZ. Powstaje ona i funkcjonuje w społeczeństwach krajów rozwijających się, czasami wywodzących się z konfliktów zbrojnych, przechodzących transformację ustrojową oraz wysoko rozwiniętych ${ }^{4}$.

Kongresy są organizowane regularnie co pięć lat każdorazowo w innym państwie. Precyzując, ich przygotowywanie pozostaje w gestii Biura ds. Przestępczości i Narkotyków Sekretariatu ONZ. Rok 2020 miał w tym kontekście wyjątkowe znaczenie - przypadała bowiem wówczas 75 rocznica funkcjonowania ONZ. Data ta miała szczególny charakter także z racji przygotowywanego na kwiecień 2020 roku XIV Kongresu ONZ w sprawie zapobiegania przestępczości i sprawiedliwości karnej, który z powodu globalnej pandemii COVID-19 został przełożony na marzec 2021 roku. Pierwotna data przypadała na jubileusz sześćdziesięciopięciolecia działalności ONZ w zakresie wypracowywania i wcielania w życie standardów dotyczących zapobiegania przestępczości i postępowania z przestępcami (sprawiedliwości karnej). Gospodarzem XIV Kongresu - po raz drugi w historii — była w roku 2021 dawna japońska stolica Kyoto.

Dokonując przeglądu literatury, zwłaszcza kryminologicznej, można znaleźć szereg istotnych informacji świadczących o znaczącym udziale merytorycznym zarówno przedstawicieli Polski, w tym polskiego środowiska naukowego oraz praktyków organów ścigania i wymiaru sprawiedliwości, w pracach nad przygotowaniem kolejnych kongresów, jak i ich aktywnym udziale w obradach kongresowych ${ }^{5}$. Celowe wydaje się więc dokonanie w tym zakresie zbiorczego podsumowania uwzględniającego zwłaszcza znaczenie kongresów w zakresie działań na rzecz zbliżenia poszczególnych systemów prawnych i realizowanej w nich praktyki organów ścigania oraz wymiaru sprawiedliwości. Ranga kongresów przekładała się bowiem na wypracowywane przez to gremium standardy zapobiegania przestępczości i działań na rzecz ochrony praw człowieka na wielu płaszczyznach: światowej, regionalnej i wewnątrzpaństwowej.

I Kongres Organizacji Narodów Zjednoczonych w sprawie zapobiegania przestępczości i postępowania z przestępcami ${ }^{6}$, bez udziału delegacji krajów socjalistycznych, w odbył się w 1955 roku w Genewie. Jego obrady były zdominowane problematyką kary pozbawienia wolności i resocjalizacji skazanych. Dyskutowano w szczególności na takie tematy, jak kształcenie i selekcja personelu więziennego, funkcjonowanie zamkniętych i otwartych zakładów

${ }^{4}$ Zob. S. Redo, Zwalczanie przestępczości zorganizowanej w Azji Centralnej, Warszawa 2007, s. 28.

5 Sygnalizacyjne - z uwagi na ograniczenia wydawnicze - nawiązanie do tej kwestii zawiera najnowszy podręcznik kryminologii: E.W. Pływaczewski et al., Kryminologia. Stan i perspektywy rozwoju. Z uwzględnieniem Agendy ONZ na rzecz zrównoważonego rozwoju 2030, Warszawa 2019, s. $100 \mathrm{n}$.

6 The First United Nations Congress on the Prevention of Crime and the Treatment of Offenders, Geneva, Switzerland, 22 August - 3 September 1955. 
karnych, praca więźniów oraz zapobieganie przestępczości nieletnich i postępowanie $\mathrm{z}$ nieletnimi osadzonymi. W odniesieniu do tej ostatniej tematyki przyjęto rekomendację ukierunkowaną na zapobieganie przestępczości nieletnich poprzez społeczność, rodzinę, szkołę oraz służby socjalne. Druga z przyjętych rekomendacji dotyczyła selekcji i kształcenia personelu więziennego. Ukoronowaniem zaś kongresu było przyjęcie przez 512 jego uczestników (reprezentujących 51 państw i 43 organizacje pozarządowe) $)^{7}$ pierwszego dokumentu o dużym znaczeniu dla wielu systemów prawnych - reguł minimalnych Organizacji Narodów Zjednoczonych dotyczących postępowania $\mathrm{z}$ więźniami ${ }^{8}$.

Miejscem kolejnych 13 kongresów były: Londyn (1960), Sztokholm (1965), Kioto (1970), Genewa (1975), Caracas (1980), Mediolan (1989), Hawana (1990), Kair (1995), Wiedeń (2000), Bangkok (2005), Salvador (2010), Katar (2015) oraz Kioto (2021). Kongresy te wpisują się zarówno w okres PRL-u — poprzedniej formacji ustrojowej, jak i w początek polskiej transformacji oraz nowe milenium.

\section{Kongresy ONZ w sprawie zapobiegania przestępczości i postępowania z przestępcami w okresie 1960-1985}

II Kongres $\mathrm{ONZ}$ w sprawie zapobiegania przestępczości i postępowania z przestępcami ${ }^{9}$ miał miejsce $\mathrm{w}$ Londynie. Obrady koncentrowały się głównie na nowych formach przestępczości nieletnich, ich przyczynach oraz zapobieganiu i postępowaniu z tą kategorią sprawców. Głównym hasłem kongresu była działalność specjalnych służb policyjnych w zakresie zapobiegania przestępczości nieletnich i postępowania z nieletnimi przestępcami. W poszczególnych sekcjach dyskutowane były między innymi takie problemy, jak nowe formy przestępczości nieletnich i ich przyczyny, zapobieganie przestępczości nieletnich i postępowanie z nieletnimi przestępcami ze szczególnym uwzględnieniem działalności specjalnych służb policyjnych, zapobieganie formom przestępczości związanym z przemianami społecznymi i ekonomicznymi w krajach słabo rozwiniętych, kary krótkoterminowego pozbawienia wolności, jak również postępowanie z więźniami w czasie odbywania kary, opieka nad

7 Źródłem prezentowanej w niniejszym opracowaniu statystyki kolejnych kongresów w latach 1955-2010 jest: UNODC - United Nations Office on Drugs and Crime, United Nations Congresses on Crime Prevention and Criminal Justice - 55 years of achievement, United Nations Information Service, Vienna. February 2010.

8 Od 2015 roku - Reguły Nelsona Mandeli. Polski przekład zawiera dodatek specjalny do „Przeglądu Więziennictwa” 1958, nr 4.

9 Second United Nations Congress on the Prevention on Crime and the Treatment on Offenders, London, England, 8-19 August 1960. 
zwalnianymi z więzień, włączenie pracy więźniów w funkcjonowanie krajowego systemu gospodarczego oraz problem wynagradzania więźniów za pracę ${ }^{10}$.

$\mathrm{W}$ odniesieniu do tych zagadnień, jak również planów zapobiegania przestępczości na szczeblu krajowym przyjęte zostały odpowiednie rezolucje. Między innymi podkreślano niecelowość stosowania kar dotyczących krótkich okresów (to jest - do sześciu miesięcy pozbawienia wolności), uznając je za jedno ze źródeł demoralizacji więźniów po raz pierwszy karanych za błahe przestępstwa. Zalecenia szły w kierunku wykorzystania zespołu środków zastępujących takie kary w postaci na przykład warunkowego zawieszenia wykonania kary, probation, kary grzywny czy pracy skazanego w warunkach wolności dozorowanej. W kongresie po raz pierwszy uczestniczyły delegacje państw socjalistycznych, członków ONZ, w tym Polski. Brał w nim także udział wybitny kryminolog polskiego pochodzenia sir Leon Radzinowicz (1906-1999) pełniący wówczas na Uniwersytecie Cambridge funkcję dyrektora Instytutu Kryminologii, którego był założycielem. Zwraca też uwagę znaczący wzrost liczby uczestników — do poziomu 1046. Reprezentowali oni 68 państw i 50 organizacji pozarządowych.

Głównym przedmiotem obrad III Kongresu ONZ w sprawie zapobiegania przestępczości i postępowania z przestępcami, który odbywał się w Sztokholmie $^{11}$, było zapobieganie przestępczości ze szczególnym uwzględnieniem analizy związków pomiędzy przestępczością a zmianami społecznymi. Problematyka ta została rozwinięta w ramach pięciu szczegółowych tematów - w ujęciu hasłowym obejmowały one zmiany społeczne a przestępczość, społeczne aktywności w zapobieganiu przestępczości, społeczności a zapobieganie przestępczości, specjalne środki profilaktyczne i lecznicze wobec nieletnich i młodocianych sprawców oraz środki ograniczania recydywy. Kongres po raz pierwszy zwrócił uwagę na zagadnienie pomocy technicznej w zakresie zapobiegania przestępczości i wymiaru sprawiedliwości, podkreślając przy tym potrzebę prowadzenia badań kryminologicznych ukierunkowanych na zapobieganie przestępczości. Zalecił również stosowanie wszelkich możliwych odmian probacji i innych środków, które nie polegają na pozbawieniu wolności, co można odczytać jako pierwsze symptomy utraty wiary w możliwości resocjalizacyjne kary pozbawienia wolności i wyraźne rysy w modelu resocjalizacji poprzez karę pozbawienia wolności. Na rzecz dokonań kongresu i wypracowywanych w czasie jego obrad inicjatyw należy też zapisać utworzenie w 1968 roku w Rzymie

10 Zob. S. Walczak, Wspótczesne tendencje $w$ dziedzinie pracy penitencjarnej i zwalczania przestępczości. Refleksje w związku z II Kongresem ONZ w sprawie zapobiegania przestępczości i postępowania z przestepcami, „Państwo i Prawo” 1961, nr 4-5, s. 585 n.; B. Hołyst, Kryminologia. Podstawowe problemy, Warszawa 1977, s. 58.

11 Third United Nations Congress on the Prevention on Crime and the Treatment on Offenders, Stockholm, Sweden, 9-18 August 1965. Under the theme: „Prevention on Criminality”. Zob. S. Walczak, Wywiad, „Służba Penitencjarna” 1965, nr 9. 
Instytutu Badań nad Obroną Społeczną ${ }^{12}$. Pokłosiem omawianego kongresu była także Konwencja Narodów Zjednoczonych z 26 listopada 1968 roku o niestosowaniu przedawnienia wobec zbrodni wojennych i przeciwko ludzkości ${ }^{13}$.

Aktywny udział delegacji polskiej w obradach kongresowych łączył się $\mathrm{z}$ przedstawieniem sześciu referatów związanych z tematyką kongresu, które dotyczyły: 1. zmian społecznych a przeciwdziałania przestępczości; 2. roli społeczeństwa, rodziny, wykształcenia zawodu w przeciwdziałaniu przestępczości; 3. społecznego programu przedsięwzięć profilaktycznych zapobiegania przestępczości nieletnich; 4. zapobiegania recydywie; 5. środków stosowanych wobec przestępców niezwiązanych $\mathrm{z}$ umieszczeniem w zakładzie karnym; 6. środków specjalnych profilaktycznych i traktowania młodocianych przestępców ${ }^{14}$. Odnotować też trzeba niewielki wzrost liczby uczestników (1083) reprezentujących większą liczbę państw (74) i mniejszą (39) — organizacji pozarządowych.

$\mathrm{Na}$ IV Kongresie ONZ w sprawie zapobiegania przestępczości i postępowania $\mathrm{z}$ przestępcami $\mathrm{w}$ Kioto ${ }^{15}$ główne hasło określono jako „Przestępc zość a rozwój”. Obradowano nad czterema tematami, to jest - polityką ochrony społecznej w związku z planowaniem narodowego rozwoju, udziałem społeczeństwa w zapobieganiu i zwalczaniu przestępczości (zwłaszcza nieletnich) w kontekście rozwoju społecznego, organizacją badań służących doskonaleniu polityki w dziedzinie ochrony społecznej oraz regułami minimalnymi ONZ dotyczącymi postępowania z osobami pozbawionymi wolności z uwzględnieniem zmian dokonujących się w reedukacji ${ }^{16}$.

Na szczególne podkreślenie zasługuje fakt, iż był to pierwszy kongres, który przyjął deklarację wzywającą państwa do podjęcia efektywnych działań koordynujących i intensyfikujących strategie zapobiegania przestępczości w kontekście rozwoju ekonomicznego i społecznego. Jego uczestnicy byli zgodni, że podstawowym zadaniem stojącym przed narodami i krajami w dziedzinie walki z przestępczością jest takie organizowanie i kształtowanie dalszego rozwoju, któremu towarzyszyłyby maksymalnie ograniczone negatywne skutki uboczne w postaci przestępczości. Osiągnięcie tego byłoby możliwe tylko wówczas, gdy planowanie ochrony społecznej, a więc zapobieganie i zwalczanie przestępczości, stałoby się nieodłączną, integralną częścią planowania ogólnego rozwoju — wszelkie przedsięwzięcia w zakresie rozwoju ekonomiki, a także oświaty, kultury, ochrony zdrowia, zabezpieczenia społecznego itp. powinny zatem uwzględniać

12 The United Nations Social Defence Research Institute. W dniu 24 maja 1989 roku zmieniona została nazwa Instytutu na Międzyregionalny Instytut Badań nad Przestępczością i Sprawiedliwości ONZ (UNICRI). Rezolucja ECOSOC nr 1989/56.

13 Dz.U. z 1970 r. Nr 26, poz. 208.

14 S. Walczak, op. cit.

15 Fourth United Nations Congress on the Prevention on Crime and the Treatment on Offenders, Kyoto, Japan, 17-26 August 1970. Under the theme: „Crime and Development”.

16 Zob. J. Smoleński, IV Kongres ONZ w sprawie zapobiegania przestępczości i zapobiegania przestępcami, „Problemy Praworządności” 1970, nr 11-12, s. 13 n. 
przewidywane następstwa w postaci przestępczości i być zsynchronizowane z odpowiednimi przedsięwzięciami przeciwdziałającymi. W myśl ustanowień kongresu prawdziwie skuteczne zwalczanie przestępczości nie może ograniczać się do reagowania na już popełnione przestępstwa i ukształtowane czynniki kryminogenne, ale powinno ingerować znacznie wcześniej. Przedmiotem obrad był też niepodejmowany wcześniej problem terroryzmu związany $\mathrm{z}$ narastającymi w skali światowej zjawiskami ekstremistycznymi, w tym porwaniami samolotów. Po raz pierwszy kongres był poprzedzony regionalnymi konferencjami przygotowawczymi, które miały miejsce w Afryce, Azji, Europie, Ameryce Łacińskiej oraz na Bliskim Wschodzie.

Delegacja polska ${ }^{17}$ przygotowała na ten kongres trzy referaty: Niektóre problemy strategii walki z przestępczościa (S. Walczak); Udziat społeczeństwa w zapobieganiu i ograniczaniu przestępczości (T. Pietrzak) oraz Organizacja badań nad przestępczościa $w$ Polsce (J. Smoleński). Wprawdzie liczba uczestników kongresu zmniejszyła się do 998, lecz wzrosła reprezentacja państw (79). W kongresie uczestniczyli też przedstawiciele 31 organizacji pozarządowych.

$\mathrm{Na} \mathrm{V}$ Kongresie ONZ w sprawie zapobiegania przestępczości i postępowania z przestępcami w Genewie ${ }^{18}$ przyjęta została Deklaracja o ochronie wszystkich osób przed torturami i innym okrutnym, niehumanitarnym czy degradującym traktowaniem czy karaniem ${ }^{19}$. Między innymi sporo miejsca poświęcono nowym formom i ewolucji przestępczości w skali krajowej i międzynarodowej, w tym zorganizowanej jako biznes, zaborowi dzieł sztuki, terroryzmowi, korupcji, przestępczości drogowej i związanej z migracją oraz kosztom przestępstwa. Po raz pierwszy w historii kongresów do porządku obrad włączono problematykę funkcji i zakresu działania organów policji. Przedmiotem dyskusji były między innymi takie zagadnienia, jak rekrutacja i szkolenie policji, rola policji wobec nowych form przestępczości, stosunki policji ze społeczeństwem, współpraca międzynarodowa oraz międzynarodowy kodeks etyczny policji. W odniesieniu do innych problemów podkreślano, że świat nękany jest

17 W jej skład wchodzili: minister sprawiedliwości prof. Stanisław Walczak — jako przewodniczący, wiceminister spraw wewnętrznych i komendant główny MO gen. Tadeusz Pietrzak, sędzia Przemysław Maćkowiak oraz prokurator Prokuratury Generalnej Jerzy Smoleński. Ponadto w kongresie brał udział — jako jedyny indywidualny uczestnik z krajów socjalistycznych — prof. Remigiusz Bierzanek z Uniwersytetu Warszawskiego. Zob. J. Smoleński, op. cit., s. 14 n.

18 The Fifth United Nations Congress on the Prevention on Crime and the Treatment on Offenders, Geneva, Switzerland, 1-12 September 1975.

19 A/3452 (XXX), The Declaration on the Protection of All Persons from Being Subjected to Torture and Other Cruel, Inhuman or Degrading Treatment or Punishment. Na temat problemu ochrony przed torturami w pracach Organizacji Narodów Zjednoczonych — zob. P. Maćkowiak, Zagadnienie tortur, [w:] Problematyka przestępczości na V Kongresie Narodów Zjednoczonych, Genewa, wrzesień 1975, red. B. Hołyst, Warszawa 1976, s. 11-114; J. Skupiński, Konwencja ONZ z 10 XII 1984 r. przeciwko torturom oraz innym formom nieludzkiego traktowania, „Państwo i Prawo" 1986 , nr 11, s. 40 n. 
coraz bardziej przez akty terroru zagrażające życiu nie tylko krajowych przywódców i dyplomatów, ale również innych ludzi, których jedyną ,winą” jest ich rasa, religia bądź pochodzenie narodowe. Że akty terroru stwarzają atmosferę strachu, od której nikt nie jest wolny ${ }^{20}$.

Dodajmy, że materiały delegacji polskiej ${ }^{21}$, zaprezentowane na kongresie, po raz pierwszy zostały wydane nakładem PWN w językach rosyjskim, angielskim i francuskim. Niewielki spadek liczby uczestników (909) ponownie nie spowodował zmniejszenia się liczby reprezentowanych na kongresie państw (101), których liczba po raz pierwszy przekroczyła 100. W kongresie tym wzięli też udział przedstawiciele 33 organizacji pozarządowych. W charakterze indywidualnych uczestników, po uzyskaniu akredytacji, wystąpiło około 300 pracowników nauki i praktyki ${ }^{22}$.

VI Kongres ONZ w sprawie zapobiegania przestępczości i postępowania z przestępcami w Caracas obradował pod hasłem „Zapobieganie przestępczości a jakość życia"23, akcentując w szczególności potrzebę szerokiego wsparcia i udziału w zapobieganiu przestępczości i rozwoju alternatyw dla kary pozbawienia wolności, jak również środków reakcji na przestępstwo oraz nadużycie władzy. Jego obrady toczyły się w dwóch komitetach, jednym podkomitecie oraz grupie roboczej i obejmowały sześć następujących bloków tematycznych: 1. tendencje w przestępczości i strategia jej zapobiegania; 2 . wymiar sprawiedliwości wobec nieletnich przed i po popełnieniu przestępstwa; 3 . przestępczość a nadużycie władzy (przestępstwa i przestępcy poza zasięgiem prawa); 4. odchodzenie od kar pozbawienia wolności (tak zwana deinstytucjonalizacja) i płynące stąd konsekwencje dla postępowania z więźniami; 5. zasady i wytyczne ONZ dla wymiaru sprawiedliwości w sprawach karnych i problem kary śmierci; 6 . nowe

20 Zob. B. Hołyst, V Kongres Narodów Zjednoczonych w sprawie Zapobiegania Przestępczości i Postepowania z Przestepcami, „Państwo i Prawo” 1976, nr 1-2, s. 243 n.

21 W skład delegacji polskiej weszli: przewodniczący prof. Włodzimierz Berutowicz — ówczesny minister sprawiedliwości, gen. bryg. Marian Janicki — komendant główny Milicji Obywatelskiej, prof. Brunon Hołyst - dyrektor Instytutu Problematyki Przestępczości, dr Wojciech Michalski - dyrektor Instytutu Badania Prawa Sądowego, oraz dr Przemysław Maćkowiak naczelnik Wydziału Zagranicznego Ministerstwa Sprawiedliwości. Poza oficjalną delegacją na zaproszenie Sekretariatu ONZ w obradach uczestniczyli: prof. Leszek Lernell, który przewodniczył V sekcji kongresu poświęconej ekonomicznym i społecznym konsekwencjom przestępczości, jak również dr Krzysztof Poklewski-Koziełł, który pełnił rolę konsultanta w sekcji I traktującej o zmianach w formach i rozmiarach przestępczości w płaszczyźnie krajowej i międzynarodowej. Zob. Problematyka przestępczości na V Kongresie..., s. 7.

22 B. Hołyst, op. cit., s. 243.

23 Sixth United Nations Congress on the Prevention on Crime and the Treatment on Offenders. Caracas, Venezuela, 25 August - 5 September 1980. Under the theme „Crime prevention and the quality of life”. Zob. The Institute of Crime Problems. Research Institute on Judicial Law, Sixth United Nations Congress on the Prevention on Crime and the Treatment on Offenders. Caracas, 25 August - 5 September 1980, red. B. Hołyst, Warszawa 1980, s. 54. 
perspektywy w zapobieganiu i zwalczaniu przestępczości i rola współpracy międzynarodowej w tym zakresie.

Finalnym dokumentem kongresu była tak zwana deklaracja z Caracas $(\mathrm{Ca}$ racas Declaration $)^{24}$ — pierwszy w historii programu ONZ tego typu dokument ramowy stanowiący podsumowanie wyników obrad kongresu w zakresie zasad zapobiegania przestępczości i postępowania z przestępcami. W deklaracji podkreśla się duże zaniepokojenie społeczności międzynarodowej gwałtownym wzrostem przestępczości i jej nowych, zwłaszcza zorganizowanych, form, co hamuje rozwój społeczeństw, niszczy wartości materialne i duchowe, naraża na szwank godność ludzką, tworzy klimat strachu i wpływa negatywnie na poziom życia społeczeństwa. Podkreśla się również, iż zapobieganie przestępczości oraz wymiar sprawiedliwości należy rozpatrywać i realizować łącznie ze stanem i rozwojem wartości socjalnych i kulturowych, przy uwzględnieniu warunków ekonomicznych, zmian społecznych i systemów politycznych. Apeluje się również do poszczególnych państw o realizm w podejściu do problemów przestępczości, opieranie programów jej zapobiegania i zwalczania na obiektywnych wynikach badań nad skutecznością i rezultatami społecznymi stosowanych środków.

W kongresie aktywnie uczestniczyła czteroosobowa polska delegacja ${ }^{25}$. Jej członkowie odbyli liczne spotkania, w czasie których omówiono wiele zagadnień dotyczących międzynarodowej współpracy. Ponadto delegacja polska przedstawiła obcojęzyczne publikacje omawiające ważne zagadnienia z zakresu zapobiegania przestępczości, polskiego wymiaru sprawiedliwości i systemu penitencjarnego ${ }^{26}$. W omawianym kongresie wzięło udział 920 uczestników reprezentujących 102 delegacje rządowe i 38 pozarządowych.

Miejscem VII Kongresu ONZ w sprawie zapobiegania przestępczości i postępowania z przestępcami ${ }^{27}$, z wiodącym hasłem „Zapobieganie przestępczości dla rozwoju, sprawiedliwości, pokoju i wolności”, był Mediolan. Przedmiotem obrad było pięć głównych zagadnień: 1. nowe wymiary przestępczości w kontekście działalności prewencyjnej dotyczącej procesów

24 Dokument ONZ A/CONF.87/12.

25 Pod przewodnictwem ministra sprawiedliwości prof. Jerzego Bafii na kongresie występowali: płk Eugeniusz Grabowski, dyrektor Biura Prewencji KGMO, prof. Brunon Hołyst, dyrektor Instytutu Problematyki Przestępczości, oraz dr Przemysław Maćkowiak, pracownik naukowy Instytutu Badania Prawa Sądowego. Bafia został wybrany jednym z wiceprzewodniczących kongresu, Hołystowi powierzono zaś funkcję wiceprzewodniczącego i sprawozdawcy grupy roboczej Komitetu I zajmującej się problematyką nowych perspektyw w dziedzinie zapobiegania przestępczości.

26 Zob. Od redakcji, [w:] Problematyka przestępczości na VI Kongresie Narodów Zjednoczonych, Caracas, 25 sierpnia - 5 września 1980, red. B. Hołyst, Warszawa 1983, s. 7; A. Marek, Główne tendencje polityki kryminalnej na forum ONZ a reforma polskiego prawa karnego, „Państwo i Prawo" 1983, nr 1, s. 84-85.

27 The Seventh United Nations Congress on the Prevention on Crime and the Treatment on Offenders. Milan, Italy, 26 August - 6 September 1980. Under the theme: „Crime prevention for freedom, justice, peace and development". 
rozwojowych - wyzwanie na przyszłość; 2 . perspektywy wymiaru sprawiedliwości w sprawach karnych $\mathrm{w}$ zmieniającym się świecie; 3. ofiary przestępstw; 4. młodzież, przestępczość, wymiar sprawiedliwości; 5. tworzenie i stosowanie norm oraz standardów ONZ dotyczących wymiaru sprawiedliwości w sprawach karnych.

Na szczególną uwagę zasługuje fakt, iż problematyka ofiar przestępstw zwłaszcza w aspekcie właściwego nastawienia do nich wymiaru sprawiedliwości oraz wyrównywania szkód wyrządzonych ofiarom działań przestępnych, w tym nadużycia władzy — po raz pierwszy stała się przedmiotem obrad kongresowych. W tym zakresie przyjęto rezolucję pod hasłem „Deklaracja podstawowych zasad sprawiedliwości odnośnie do ofiar przestępczości i ofiar nadużycia władzy”. Na uwagę zasługuje również uchwalenie reguł minimalnych postępowania z nieletnimi (reguł pekińskich), w których położono nacisk na specyficzne wychowawcze metody oddziaływania. Kongres przyjął również — w formie uchwały — ważny dokument o nazwie Mediolański Plan Działania (Milan Plan of Action), w którym między innymi zaleca się $\mathrm{w}$ celu przeciwdziałania przestępczości zwiększanie dobrobytu społeczeństwa. Przyjęto również kilka nowych standardów i norm Narodów Zjednoczonych, mieszczących się w zakresie ogólnego jego wiodącego hasła.

W przygotowaniu materiałów na VII Kongres brały udział trzy polskie resorty: Ministerstwo Sprawiedliwości, Ministerstwo Spraw Wewnętrznych i Prokuratura Generalna ${ }^{28}$. Delegacja polska odegrała wówczas ważną rolę — przygotowała bowiem raporty na temat wszystkich zagadnień poruszanych podczas kongresu $^{29}$, a także wiele innych dokumentów na poszczególne spotkania. Minister sprawiedliwości Lech Domeracki został wybrany wiceprzewodniczącym kongresu, a ponadto przypadła mu też rola wygłoszenia przemówienia $\mathrm{w}$ imieniu europejskich krajów socjalistycznych na końcowej sesji ${ }^{30}$. W kongresie

28 Jak wynika z relacji dyrektora gabinetu ówczesnego Ministerstwa Sprawiedliwości sędziego Wojciecha Tomczyka, przedstawiciele Polski aktywnie uczestniczyli w spotkaniach przygotowawczych do kongresu. Zob. W. Tomczyk, Gtos w dyskusji, [w:] ONZ a zwalczanie przestępczości, „Gazeta Prawnicza” 15 (508), 1.08.1985, s. 4. Do składu delegacji polskiej, której przewodniczył minister sprawiedliwości dr Lech Domeracki, zostali powołani: prof. Brunon Hołyst, dr Przemysław Maćkowiak z Instytutu Badania Prawa Sądowego, doc. Karol Sławik, dyrektor w Ministerstwie Spraw Wewnętrznych, oraz sędzia Wojciech Tomczyk, dyrektor gabinetu ministra sprawiedliwości. Ponadto w kongresie uczestniczyli dr Ewa Bieńkowska (PAN), doc. Marian Filar (UMK), doc. Jerzy Jasiński (PAN), doc. Zofia Ostrihanska (PAN) oraz dr Krzysztof Poklewski-Koziełł, sekretarz redakcji „Państwa i Prawa”.

29 Zob. między innymi M. Filar, Przestępczość i jej zapobieganie $w$ warunkach wdrażania nowego międzynarodowego tadu gospodarczego (z perspektywy europejskich państw socjalistycznych), [w:] Problematyka przestępczości na VII Kongresie Narodów Zjednoczonych, Mediolan, 26 sierpnia - 6 września 1985, red. B. Hołyst, Warszawa 1977, s. 27-42.

30 Natomiast prof. Brunon Hołyst brał udział w dyskusji na temat kwestii wiktymologicznych, podkreślając między innymi rolę organów prokuratury w zakresie zabezpieczania interesów pokrzywdzonego. Zob. Od redakcji, [w:] Problematyka przestępczości na VII Kongresie..., s. 5. B. Hołyst, Sprawozdanie z VII Kongresu Narodów Zjednoczonych w Sprawach Zapobiegania 
tym wzięło udział 1395 uczestników reprezentujących 125 delegacji rządowych i 58 organizacji pozarządowych.

\section{Kongresy ONZ w sprawie zapobiegania przestępczości i postępowania z przestępcami (sprawiedliwości karnej) na początku okresu polskiej transformacji i w nowym milenium}

VIII Kongres ONZ w sprawie zapobiegania przestępczości i postępowania $z$ przestępcami $w$ Hawanie ${ }^{31}$ przypada na początek okresu transformacji w Polsce. Główny przedmiot obrad objęty został ogólnym hasłem „Międzynarodowe zapobieganie przestępczości i wymiar sprawiedliwości w XXI wieku". Jedną z podstawowych kwestii w tym zakresie był problem zapobiegania przestępczości zorganizowanej i terroryzmowi oraz rodzaj środków mających na celu zwalczanie terroryzmu międzynarodowego. Kongres obradował w pięciu sekcjach tematycznych: 1. zapobieganie przestępczości i wymiar sprawiedliwości karnej: realia i perspektywy współpracy międzynarodowej; 2. polityka kryminalna związana z problemami kary pozbawienia wolności i innych kar oraz środków zastępczych; 3. skuteczna działalność krajowa i międzynarodowa skierowana przeciw przestępczości zorganizowanej oraz akcjom przestępczym o charakterze terrorystycznym; 4. zapobieganie przestępczości młodzieży, wymiar sprawiedliwości wobec nieletnich i ochrona młodzieży: kryteria normatywne i kierunki działania; 5. normy i wytyczne Organizacji Narodów Zjednoczonych w dziedzinie zapobiegania przestępczości i wymiaru sprawiedliwości karnej: ich stosowanie i priorytety w zakresie opracowania nowych norm.

Poza oficjalną delegacją naszego kraju ${ }^{32}$ w kongresie uczestniczyli także w charakterze indywidualnych ekspertów - reprezentujący UMK Marian Filar (1942-2020) i Emil W. Pływaczewski. M. Filar był autorem obszernej ekspertyzy ${ }^{33}$,

Przestępczości i postępowania ze Sprawcami (Mediolan 26 sierpnia - 6 września 1985), „Problemy Praworządności" 1985, nr 11, s. 93-94.

31 The Eight United Nations Congress on the Prevention on Crime and the Treatment on Offenders. Havana, Cuba, 27 August - 7 September 1990. Under the theme: „International crime prevention and criminal justice in the twenty-first century".

32 Delegacja krajowa, pod przewodnictwem ministra sprawiedliwości Aleksandra Bentkoskiego, liczyła siedem osób. W jej skład weszli: Ryszard Grupiński (Instytut Badania Prawa Sądowego), Barbara Kunicka-Michalska (PAN), Bogusław Strzelecki (Komenda Główna Policji), Marian Miklasz (Ministerstwo Sprawiedliwości), Zbigniew Stankiewicz (Ministerstwo Sprawiedliwości) oraz Stanisław Raczke (polska ambasada na Kubie).

33 Pod tytułem Criminal Justice Police in the Crossnational Perspective in Relation to Crime Trends and Crime Prevention Strategies. Current and Future Development sporządzonej w ramach przygotowań do tego kongresu — na zlecenie The Commisiion of Crime Prevention and Criminal Justice Branch UN w Wiedniu. 
która w 1991 roku została opublikowana w Polsce ${ }^{34}$. Warto też podkreślić, iż delegacja polska wniosła istotne poprawki do reguł z Tokio, to jest - reguł minimalnych w zakresie środków niepolegających na pozbawieniu wolności. Polska również znalazła się wśród państw inicjujących niektóre rezolucje. Jak podkreśla Barbara Kunicka-Michalska (PAN), wkład obecnych na kongresie Polaków w jego obrady był znaczny ${ }^{35}$. W kongresie tym wzięło udział 1127 uczestników reprezentujących 127 delegacji rządowych i 46 pozarządowych.

Kolejnym kongresem przypadającym na pierwszą pięciolatkę transformacji ustrojowej w Polsce był IX Kongres ONZ w sprawie zapobiegania przestępczości i postępowania z przestępcami ${ }^{36}$ w Kairze, obradujący pod hasłem "Mniej przestępczości, więcej sprawiedliwości: bezpieczeństwo dla w szystkich". Położył on szczególny nacisk na współpracę międzynarodową i praktyczną pomoc techniczną dla wzmocnienia zasady rządów prawa, ujmując to wspomnianym wyżej ogólnym hasłem. Do pięciu szczegółowych tematów kongresu zaliczono: działania wobec ponadnarodowej i zorganizowanej przestępczości, rolę prawa karnego w ochronie środowiska, wymiar sprawiedliwości karnej a systemy policyjne, strategie zapobiegania przestępczości w obszarach miejskich oraz przestępczość nieletnich. Rekomendacje dotyczące wspomnianej pomocy technicznej obejmowały programy warsztatowe oraz zorientowane na konkretne działania badania, a także analizy na płaszczyźnie regionalnej, subregionalnej oraz lokalnej.

Godnym odnotowania wydarzeniem na kongresie w Kairze było zaprezentowanie, po raz pierwszy w historii polskiego udziału w tych kongresach, polskiego raportu obejmującego węzłowe kwestie dotyczące przestępczości i jej kontroli przygotowanego przez Instytut Wymiaru Sprawiedliwości pod egidą Ministerstwa Sprawiedliwości ${ }^{37}$.

34 Zob. M. Filar, Criminal Justice Police in the Crossnational Perspective, Torun 1991, s. 77.

35 Szerzej zob. B. Kunicka-Michalska, VIII Kongres ONZ w sprawie zapobiegania przestepczości i postępowania z przestępcami (Hawana, 27 VIII - 7 IX 1990), „Państwo i Prawo” 1991, nr 8, s. 96-100. Zob. także E. Zielińska, J. Jasiński, K. Poklewski-Koziełł, Zapobieganie przestępczości i postepowanie z przestępcami (IX Kongres NZ, Kair, 29 IV - 8 V 1995), „Państwo i Prawo” 1995, nr 8; E.W. Pływaczewski, Komunikat z Kongresu Organizacji Narodów Zjednoczonych w Kairze, „Przegląd Policyjny” 1996, nr 1.

36 The Ninth United Nations Congress on the Prevention on Crime and the Treatment on Offenders. Cairo, Egypt, 28 April - 5 May 1995. Under the theme: „Seeking security and justice for all”.

37 Zob. Crime Control in Poland. Polish Report for the Ninth United Nations Congress on the Prevention of Crime and the Treatment of Offenders (Cairo, Egypt, 29 April - 8 May 1995), red. J. Jasiński, A. Siemaszko, Warszawa 1995, s. 96. Jego współautorami byli następujący przedstawicieli nauki i praktyki: Józef Gemra (Ministerstwo Sprawiedliwości), Beata Gruszczyńska (IWS, UW), Jerzy Jasiński (PAN), Andrzej Kojder (UW), Marek Marczewski (IWS), Wiktor Mikusiński (Komenda Stołeczna Policji), Andrzej Murzynowski (UW, Sąd Najwyższy), Felicja Myszurska (Ministerstwo Sprawiedliwości), Emil W. Pływaczewski (UW - Wydział Prawa w Białymstoku), Wojciech Radecki (PAN), Andrzej Siemaszko (IWS) oraz Dobrochna Wójcik (PAN, IWS). 
Niezależnie od kilkunastoosobowej oficjalnej polskiej delegacji ${ }^{38} \mathrm{w}$ kongresie uczestniczyli także - w charakterze indywidualnych ekspertów - naukowcy Barbara Kunicka-Michalska (PAN), Marian Filar (UMK), Andrzej Adamski (UMK), Krzysztof Poklewski-Koziełł (sekretarz redakcji „Państwa i Prawa”) oraz Emil W. Pływaczewski (UW - Wydział Prawa w Białymstoku).

Pierwszym kongresem w nowym milenium był X Kongres ONZ w sprawie zapobiegania przestępczości i postępowania z przestępcami ${ }^{39}$, który obradował w Wiedniu pod hasłem „Przestępczość i sprawiedliwość wobec wyzwań XXI wieku”. Szerzej niż dotychczas dyskutowano tam, jak promować zasadę rządów prawa i w jaki sposób wzmocnić wymiar sprawiedliwości karnej. Ponadto kategoria szczegółowych tematów kongresu obejmowała współpracę międzynarodową $\mathrm{w}$ zwalczaniu ponadnarodowej przestępczości zorganizowanej, efektywne zapobieganie przestępczości w kontekście nowych społecznych tendencji rozwojowych, zwalczanie korupcji, przestępstwa związane z sieciami komputerowymi, włączanie społeczności w zapobieganie przestępczości oraz rolę kobiet w systemie wymiaru sprawiedliwości karnej.

Najważniejszym efektem omawianego kongresu było przyjęcie przez aklamację Deklaracji wiedeńskiej w sprawie przestępczości i sprawiedliwości $\mathrm{i}^{40}$, w której państwa członkowskie zobowiązały się do podjęcia konkretnych i szybkich działań dotyczących środków zwalczania terroryzmu, handlu ludźmi, nielegalnego handlu bronią, przerzutu migrantów i prania brudnych pieniędzy. Ponadto w ramach poszczególnych założeń dokumentu kraje członkowskie zadeklarowały wzmocnienie działań międzynarodowych na rzecz zwalczania korupcji i podkreśliły potrzebę wypracowania nowych prawnych instrumentów międzynarodowych w nawiązaniu do konwencji ONZ przeciwko przestępczości zorganizowanej ${ }^{41}$.

W kongresie w Wiedniu uczestniczyła najliczniejsza jak dotąd polska delegacja z instytucji i urzędów oraz przedstawicieli nauki prawa karnego i kryminologii.

${ }^{38} \mathrm{Z}$ ministrem sprawiedliwości prof. Jerzym Jaskiernią na czele. W tym gronie (liczącym 15 osób) — obok polityków, przedstawicieli organów ścigania i wymiaru sprawiedliwości — występowali także naukowcy w osobach profesorów Eleonory Zielińskiej (UW) i Jerzego Jasińskiego (1930-1998) reprezentującego PAN.

39 The Tenth United Nations Congress on the Prevention of Crime Crime and the Treatment on Offenders, Vienna, Austria, $10-17$ April 2000. Under the theme „Crime and justice, meeting the challenges of the $21^{\text {st }}$ century".

40 A/55/59, The Vienna Declaration on Crime and Justice: Meeting the Challenges of the Twentyfirst Century.

41 A/55/25, United Nations Convention against Transnational Organized Crime, 15 November 2000. Warto przypomnieć, iż inicjatywa opracowania konwencji została zgłoszona przez Polskę w trakcie obrad V sesji Komisji ds. Zapobiegania Przestępczości i Wymiaru Sprawiedliwości w maju 1996 roku. Bliżej: Przestępczość zorganizowana, red. E.W. Pływaczewski, Warszawa 2011, s. $366 \mathrm{n}$. (wraz z literaturą). 
Poza delegacją oficjalną liczącą 15 osób $^{42}$, na czele z minister sprawiedliwości Hanną Suchocką, w charakterze ekspertów indywidualnych w kongresie brali udział Andrzej Adamski (UMK), Grażyna Kopińska (dyrektor programu „Przeciw korupcji”) oraz Emil W. Pływaczewski (UwB). Zaprezentowany wówczas został kolejny polski raport dotyczący zasadniczych kwestii związanych z przestępczością i jej kontrolą, koordynowany — podobnie jak poprzedni — przez dyrektora Instytutu Wymiaru Sprawiedliwości prof. Andrzeja Siemaszkę (1950-2021) ${ }^{43}$. Uznaje się, iż raport ten do dziś stanowi model nowatorskiego przedstawienia węzłowej problematyki przestępczości.

W 2005 roku miejscem XI Kongresu ONZ w sprawie zapobiegania przestępczości i sprawiedliwości karnej ${ }^{44}$ był Bangkok. Jego główny temat brzmiał: „Współdziałania i reakcje: strategiczne przymierza w zapobieganiu przestępczości i sprawiedliwości karnej”. Zwraca uwagę fakt, iż po raz pierwszy w nazwie kongresu odstąpiono od drugiego członu formuły, to jest - „postępowania z przestępcami”, zastępując go „sprawiedliwością karną”. W intencji organizatorów chodziło w szczególności o promowanie i wzmocnienie systemów sprawiedliwości karnej oraz współpracy międzynarodowej w tym właśnie obszarze, z uwagi na to, że obchodzono wówczas pięćdziesięciolecie działalności ONZ w zakresie zapobiegania przestępczości i postępowania z przestępcami (od czasu inicjującego kongresu tej organizacji w Genewie w 1955 roku) ${ }^{45}$.

Do wiodących tematów, nad którymi obradował kongres, zaliczono efektywność środków zwalczania transgranicznej przestępczości zorganizowanej, międzynarodową współpracę $\mathrm{w}$ obliczu terroryzmu, powiązania pomiędzy terroryzmem i innymi działaniami o charakterze kryminalnym w kontekście prac UNODC, korupcję na tle zagrożeń i trendów w XXI wieku, przestępczość ekonomiczną i finansową na tle wyzwań długotrwałego rozwoju ekonomicznego.

42 W jej składzie znaleźli się: Henryk Szlajfer, Janusz Rydzykowski, Ryszard Rychlik, Piotr Mierecki, Jarosław Robak, Dobrochna Wójcik, Irena Rzeplińska, Mariusz Skowroński, Beata Ziorkiewicz, Edyta Łapińska, Jacek Such, Jacek Najder, Marek Łukaszewicz oraz Janusz Murasicki.

43 Zob. Crime and Law Enforcement in Poland on the threshold of the $21^{\text {st }}$ century, red. A. Siemaszko, Warszawa 2000, s. 171. Jego współautorami byli następujący przedstawiciele nauki: Andrzej Adamski (UMK), Konrad Buczkowski (IWS), Beata Czarnecka-Dzialuk (IWS, PAN), Beata Gruszczyńska (UW), Andrzej Kojder (UW) Anna Kossowska (PAN, UW), Krzysztof Krajewski (UJ), Marek Marczewski (IWS), Marek Mozgawa (UMCS), Emil W. Pływaczewski (UwB), Irena Rzeplińska (IWS), Andrzej Siemaszko (IWS), Jerzy Szumski (UMCS), Michał Wojtaszek (IWS), Dobrochna Wójcik (IWS) oraz Eleonora Zielińska (UW).

44 The Eleventh United Nations Congress on Crime Prevention and Criminal Justice. Synergies and Responses: Strategic alliances in crime prevention and criminal justice, Bangkok, Thailand, 18-25 April 2005. zob. B. Kunicka-Michalska, E.W. Pływaczewski, Zapobieganie przestępczości i sprawiedliwość karna (XI Kongres Organizacji Narodów Zjednoczonych, Bangkok, 18-25 IV 2005), „Państwo i Prawo” 2006, nr 2.

45 Jubileuszowi temu zostało poświęcone specjalne sympozjum w Instytucie Nauk Prawnych PAN. Zob. J. Gomuła, Sympozjum z okazji 50-lecie Organizacji Narodów Zjednoczonych (INP PAN, 12 IX 1995), „Państwo i Prawo” 1996, nr 5, s. 92-93. 
Specjalny charakter - z uwagi na przypadający jubileusz - miał temat stanowiący reasumpcję prac Narodów Zjednoczonych nad wypracowywaniem standardów pod hasłem „Pięćdziesiąt lat wcielania w życie standardów w zakresie zapobiegania przestępczości i sprawiedliwości karnej”.

W finalnym trzydziestopięciopunktowym dokumencie kongresu - tak zwanej Deklaracji z Bangkoku ${ }^{46}$ — wyrażono między innymi nadzieję, że trwające aktualnie negocjacje nad projektem kompleksowej konwencji na temat międzynarodowego terroryzmu zostaną możliwie jak najszybciej sfinalizowane. Wezwano też państwa członkowskie do podejmowania decyzji w kwestii podpisywania i ratyfikowania Międzynarodowej Konwencji o Przeciwdziałaniu Aktom Nuklearnego Terroryzmu. W zakresie promowania praw ofiar w ślad za inicjatywą Światowego Stowarzyszenia Wiktymologii ${ }^{47}$ zaangażowanego w prace nad projektem deklaracji, a na kolejnym etapie projektem konwencji o sprawiedliwości i wsparciu dla ofiar przestępstw i nadużyć władzy, w Deklaracji z Bangkoku przyjęto:

Uznajemy znaczenie zwracania szczególnej uwagi na potrzebę ochrony świadków ofiar przestępstw oraz terroryzmu, jak też sami angażujemy się we wzmacnianie — gdzie jest to potrzebne - prawnych i finansowych ram służących zapewnieniu takim ofiarom wsparcia, mając na względzie, inter alia, deklarację o podstawowych zasadach sprawiedliwości dla ofiar przestępstw i nadużyć władzy.

W omawianej deklaracji optowano również za uniwersalną konwencją przeciwko cyberterroryzmowi, konwencją przeciwko kradzieży i handlu dobrami kultury oraz kodeksem postępowania wobec terroryzmu. W szczególności podkreślano, że terroryzm jest jednym z najpoważniejszych zagrożeń dla wolności, demokracji, praw człowieka, światowego pokoju i bezpieczeństwa oraz humanizmu. Podnoszone też były kwestie przeciwdziałania praniu brudnych pieniędzy, korupcji oraz nielegalnemu handlu w chronionych obszarach dzikiej fauny i flory ${ }^{48}$.

Poza delegacją oficjalną liczącą siedem osób ${ }^{49}$, pod przewodnictwem wiceministra spraw wewnętrznych Andrzeja Brachmańskiego, na kongresie w charakterze ekspertów indywidualnych z Polski wystąpili przedstawiciele nauki: Barbara Kunicka-Michalska (PAN) i Emil W. Pływaczewski (UwB). Reprezentantka PAN-u zabierała głos w trzech sesjach dotyczących praw dzieci jako ofiar i świadków przestępstw, środków karnych alternatywnych wobec kary pozbawienia wolności

46 A/60/177, The Bangkok Declaration - Synergies and Responses: Strategic Alliances in Crime Prevention and Criminal Justice.

47 Zob. E. Bieńkowska, Wiktymologia, Warszawa 2018, s. 92.

48 Podkreślić też trzeba, iż na omawianym kongresie nie była już niestety kontynuowana inicjatywa Ministerstwa Sprawiedliwości opracowywania przez Instytut Wymiaru Sprawiedliwości, wzorem poprzednich kongresów w Kairze i Wiedniu, polskiego raportu obejmującego węzłowe kwestie dotyczące przestępczości i jej kontroli.

49 W jej składzie znaleźli się: Andrzej Brachmanski (przewodniczący), Bogdan Góralczyk, Sylwester Królak, Krzysztof Liedl, Wieńczysław Antczak, Igor Dzialuk oraz Agnieszka Stawiarz. 
oraz terroryzmu. Z kolei E.W. Pływaczewski zaprezentował referat pod tytułem Szkolenia $w$ zakresie wymiaru sprawiedliwości karnej i kontrola przestępczości zorganizowanej w Europie Środkowej: doświadczenia z Austrii, Węier i Polski podczas sesji zatytułowanej Znaczenie $i$ wartość ksztatcenia kryminologicznego szkolenia funkcjonariuszy organów ścigania i wymiaru sprawiedliwości. W kongresie wzięło udział 129 delegacji rządowych oraz 35 organizacji pozarządowych (NGO) — w sumie ponad 3000 uczestników. Integralną częścią programu były także spotkania pomocnicze (ancillary meetings), organizowane przeważnie przez organizacje pozarządowe $\mathrm{e}^{50}$.

Głównym tematem XII Kongresu ONZ w sprawie zapobiegania przestępczości i sprawiedliwości karnej w brazylijskim Salwadorze ${ }^{51}$ było hasło „Wszechstronne (kompleksowe) strategie dla globalnych wyzwań: zapobieganie przestępczości i systemy sprawiedliwości karnej oraz ich rozwój w zmieniającym się świecie". Kongres obradował już zgodnie ze zmienioną w Bangkoku formułą, w której „postępowanie z przestępcami” zastąpiono „sprawiedliwością karną”. Na czas obrad kongresu przypadał też jubileusz pięćdziesięciopięciolecia działalności ONZ w zakresie wypracowywania i wcielania $\mathrm{w}$ życie standardów zapobiegania przestępczości i postępowania z przestępcami (sprawiedliwości karnej) ${ }^{52}$.

Do wiodących ośmiu obszarów tematycznych kongresu zaliczono: 1. dzieci i młodzież a przestępczość; 2. problematykę terroryzmu w aspekcie pomocy technicznej celem ułatwienia ratyfikacji i implementacji międzynarodowych instrumentów dotyczących zapobiegania i zwalczania tego procederu; 3. wytyczne ONZ w zakresie zapobiegania przestępczości; 4. działania systemu sprawiedliwości karnej wobec przemytu migrantów i handlu ludźmi, z uwzględnieniem związku tych patologii z transgraniczną przestępczością zorganizowaną; 5. współpracę międzynarodową $\mathrm{w}$ przeciwdziałaniu procederowi prania pieniędzy opartą

${ }^{50}$ W szczególności były to: European Institute for Crime Prevention and Control (HEUNI), United Nations Asia and Far East Institute for the Prevention of Crime and the Treatment of Offenders (UNAFEI), United Nations African Institute for the Prevention of Crime and the Treatment of Offenders (UNAFRI), International Scientific and Professional Advisory Council of the United Nations Crime Prevention and Criminal Justice Programme (ISPAC), International Consortium of Criminology Associations, American Society of Criminology (ASC), World Society of Victimology (WSV) czy Penal Reform International (PRI).

51 The Twelfth United Nations Congress on Crime Prevention and Criminal Justice. Comprehensive strategies for global challenges: crime prevention and criminal justice systems and their development in a changing world, Salvador, Brazil, 12-19 April 2010. Zob. E.W. Pływaczewski, XII Kongres Organizacji Narodów Zjednoczonych (Salwador, Brazylia, 12-19 IV 2010), „Państwo i Prawo" 2010, nr 10, s. 133-135.

52 Warto nadmienić, iż gospodarzami czterech regionalnych konferencji przygotowawczych poprzedzających XII Kongres były Costa Rica (San Jose), Katar (Doha), Tajlandia (Bangkok) oraz Kenia (Nairobi). Konferencje te, których zasadniczym celem było uwzględnienie perspektywy regionalnej w dyskusjach przewidzianych w czasie kongresu, poprzedziła XVIII Sesja Komisji Zapobiegania Przestępczości i Sprawiedliwości Karnej (Wiedeń, 16-24.04.2009). 
na instrumentach ONZ oraz innych rozwiązaniach prawnych; 6. aktualne trendy w zakresie wykorzystania nauki i technologii przez sprawców oraz organy odpowiedzialne za zwalczanie przestępczości, z uwzględnieniem problemu cyberprzestępczości; 7. praktyczne aspekty w zakresie wzmocnienia współpracy międzynarodowej w zwalczaniu przestępczości; 8. działania z zakresu zapobiegania przestępczości i reakcji systemu sprawiedliwości karnej w odniesieniu do pracowników migracyjnych i ich rodzin oraz przemocy wobec migrantów. Integralną częścią programu kongresu były także spotkania pomocnicze (ancillary meetings ${ }^{53}$.

W ramach głównych tematów kongresu między innymi szeroko nawiązywano do procesów dynamicznej urbanizacji, która wprawdzie otwiera szereg nowych możliwości w sferze gospodarczej, ale jednocześnie pociąga za sobą wiele negatywnych konsekwencji. Należy do nich w szczególności zaliczyć alienację, różne przejawy społecznej dezorganizacji - w tym chaos oraz przestępczość. Szczególnie trudne wyzwania o charakterze ekonomicznym i społecznym, łącznie ze sferą bezpieczeństwa i porządku publicznego, stoją przed krajami afrykańskimi i azjatyckimi, które doświadczają wyjątkowo dynamicznego, a przy tym niekontrolowanego wzrostu urbanizacji. Na specjalnej sesji rozwijane też były główne tezy opublikowanej w 2008 roku antologii zatytułowanej, w polskim thumaczeniu, Dla rząów prawa. Kształcenie i szkolenie w zakresie wymiaru sprawiedliwości karnej na świecie ${ }^{54}$, bazującej na doświadczeniach $\mathrm{w}$ analizie i przekazie problematyki zwalczania przestępczości między innymi w oparciu o standardy i normy ONZ dotyczące zapobiegania przestępczości i administracji wymiaru sprawiedliwości.

Spośród 44 hasłowo wyszczególnionych zagadnień kongresowych najwięcej sesji koncentrowało się wokół takich kwestii, jak prawa człowieka, międzynarodowe standardy, normy i konwencje, zapobieganie przestępczości, więziennictwo, dzieci i młodzież, reformy wymiaru sprawiedliwości, ofiary przestępstw oraz rządy prawa. Ważnym wydarzeniem kongresu było promowanie przez Światowe Stowarzyszenie Wiktymologii rekomendacji przyjętej z okazji 25 rocznicy uchwalenia deklaracji o podstawowych zasadach sprawiedliwości dla ofiar przestępstw i nadużyć władzy, w której podkreśla się wagę dalszego działania na rzecz wzmocnienia praw ofiar i ułatwiania im dostępu do wymiaru sprawiedliwości, łącznie z możliwym przyjęciem konwencji poświęconej tej problematyce ${ }^{55}$.

$53 \mathrm{~W}$ bogatej ofercie programowej ancillary meetings znalazło się 18 grup tematycznych. Ponad 80 sesji zorganizowanych w ramach tej formuły charakteryzowało się udziałem szerokiego grona uczestniczących w kongresie ekspertów indywidualnych, w tym licznej grupy członków Amerykańskiego Stowarzyszenia Kryminologii.

54 For the Rule of Law: Criminal Justice Teaching and Training@ Cross the World. HEUNI, red. K. Aromaa, S. Redo, Helsinki-Seoul 2008. Celem tej pierwszej na międzynarodowym rynku publikacji było rozpoczęcie bardziej usystematyzowanej wymiany doświadczeń edukacyjnych, w rezultacie której można by planować działania dla harmonizacji programów nauczania na uczelniach wyższych i w placówkach szkoleniowych na świecie.

55 Zob. E. Bieńkowska, op. cit., s. 92. 
Dużym zainteresowaniem cieszyła się też sesja zorganizowana przez UNODC, HEUNI i Northeastern University (Boston) poświęcona analizie najnowszych statystyk dotyczących międzynarodowych trendów przestępczości oraz funkcjonowania systemów wymiaru sprawiedliwości karnej ${ }^{56}$, na której zaprezentowano słabe strony oficjalnych statystyk przestępczości, wskazując na różnego rodzaju niedoskonałości w procesie ich tworzenia oraz interpretacji.

Finalnym dokumentem kongresu była Deklaracja z Salwadoru eksponująca $\mathrm{w}$ nazwie główny jego temat. W tym obszernym dokumencie między innymi potwierdzono uniwersalny charakter norm Narodów Zjednoczonych w zakresie prewencji przestępczości, przy jednoczesnym wskazaniu na potrzebę ich aktualizacji i doskonalenia ${ }^{57}$.

Jednym z nowych elementów, w porównaniu do Deklaracji z Bangkoku, jest szerokie uwzględnienie zagrożeń wobec dzieci i młodzieży, połączone $\mathrm{z}$ apelem o skuteczniejsze przeciwdziałanie przestępczości w tych grupach wiekowych oraz konieczność rehabilitacji i reintegracji młodych przestępców. Wskazuje się też na zagrożenie przestępczością seksualną dzieci i młodzieży, konieczność ochrony dzieci-ofiar i dzieci-świadków przestępstw oraz dzieci i młodzieży przed materiałami motywującymi do działań przestępnych. Zwracając uwagę na zagrożenia związane z przestępczymi działaniami wobec kobiet, deklaracja apeluje jednocześnie o jednakowe traktowanie osób obojga płci w działaniach prewencyjnych i dostępie do systemu wymiaru sprawiedliwości.

W odniesieniu do kwestii migrantów i ich rodzin zaleca się wprowadzanie w życie ratyfikowanych międzynarodowych uregulowań prawnych chroniących ich prawa. Niezależnie od tego państwa członkowskie powinny zwracać szczególną uwage na kwestie zapobiegania zarówno przemytowi migrantów, jak i handlowi ludźmi, łącznie z prowadzeniem odpowiednich kampanii uświadamiających i ochroną ofiar wymienionych kategorii przestępstw. Biorąc zaś pod uwagę podatność migrantów na różnego rodzaju akty przemocy, powinno się odpowiednio zabezpieczać ich prawa zgodnie ze standardami międzynarodowych praw człowieka i prawa humanitarnego.

Tradycyjnie niejako nawiązuje się też do potrzeby wprowadzenia do krajowych systemów sprawiedliwości karnej efektywnych strategii prewencyjnych i środków zwalczania terroryzmu we wszelkich jego formach i przejawach, włączając $w$ to finansowanie tego procederu. W związku z tym deklaracja rekomenduje państwom członkowskim rozwijanie odpowiednich strategii celem określenia i nadania priorytetu kluczowym kwestiom w zakresie programów szkoleniowych

56 Sesja „International Statistics on Crime and Justice”, połączona z promocją opracowania: International Statistics on Crime and Justice, red. S. Harrenford, M. Heiskanen, S. Malby, Helsinki 2010. Zawiera ono pierwszą w skali światowej analizę wyników „,the United Nations Crime Trends Survey".

57 Zob. S. Redo, Międzynarodowe zasady zapobiegania przestępczości, ,Przegląd Policyjny” 2009 , nr 2, s. 5 n. 
ukierunkowanych na przeciwdziałanie terroryzmowi i jego finansowaniu, przy uwzględnieniu krajowych priorytetów i realiów. Strategie te powinny wszakże pozostawać $\mathrm{w}$ pełnej zgodności $\mathrm{z}$ prawem międzynarodowym, włączając $\mathrm{w}$ to prawa człowieka, prawa uchodźców i prawo humanitarne.

Omawiany dokument nie pomija też — szeroko dyskutowanych w czasie kongresu - kwestii związków pomiędzy handlem narkotykami a innymi formami przestępczości zorganizowanej, takimi jak pranie pieniędzy, handel ludźmi, przemyt migrantów, porwania $\mathrm{i}$ handel bronią. W związku $\mathrm{z}$ tym podkreśla się znaczenie eksponowania i promowania dobrych praktyk w zakresie neutralizowania tych związków na płaszczyźnie krajowej, regionalnej i międzynarodowej.

W deklaracji nie mogło też zabraknąć odniesienia do problemu wykorzystywania technologii informatycznych i innych zdobyczy technologicznych, w tym coraz większego zasięgu internetu, do popełniania określonych kategorii przestępstw. Cyberprzestępczość jest problemem, który wymaga natychmiastowej i skoordynowanej akcji międzynarodowej, łącznie z rozważeniem możliwości wypracowania międzynarodowej, uniwersalnej regulacji w tym przedmiocie.

Nawiązuje się też do coraz częściej eksponowanej, zarówno w wymiarze krajowym, jak i międzynarodowym, problematyki ochrony dziedzictwa kulturowego oraz środowiska naturalnego. W płaszczyźnie środowiska naturalnego deklaracja podkreśla wyzwania wynikające z przestępstw skierowanych przeciw środowisku i zachęca państwa członkowskie do wzmocnienia krajowych strategii ich zapobiegania i zwalczania. Powinno się to łączyć ze wzmocnieniem międzynarodowej współpracy, włączając w to pomoc techniczną i wymianę dobrych praktyk.

Sporo miejsca w deklaracji poświęca się problematyce penitencjarnej. Przede wszystkim podkreśla się, iż system penitencjarny stanowi jeden z kluczowych komponentów systemu wymiaru sprawiedliwości karnej, zaś standardy i normy ONZ dotyczące postępowania z więźniami powinny być źródłem wskazań i inspiracji w zakresie rozwijania bądź aktualizacji krajowych kodeksów dotyczących zarządzania więziennictwem. Podkreśla się potrzebę wzmocnienia alternatyw wobec kary pozbawienia wolności, wspierania rehabilitacji i programów reintegracyjnych, włącznie z edukacyjnymi i postpenitencjarnymi dla więźniów, jak również wzięcia pod uwagę szczególnych wyzwań wynikających z faktu, iż w wielu krajach znaczny odsetek populacji więziennej stanowią cudzoziemcy.

Duży nacisk jest też położony na wzmacnianie współpracy międzynarodowej, która jest niezbędnym elementem w zwalczaniu przestępczości zorganizowanej, zwłaszcza że dotychczasowe zmiany mające na celu usprawnienie tej współpracy są niewystarczające. Stąd postulaty zwiększenia efektywności współpracy w zakresie ekstradycji, udzielania wzajemnej pomocy, konfiskaty majątku i innych ukierunkowanych na zwalczanie przestępczości zorganizowanej. Jeśli władze krajowe nie wprowadzą możliwie szybko mechanizmów usprawniających współpracę międzynarodową to — jak podkreśla się w konkluzjach i rekomendacjach kongresu — może dojść do sytuacji, że gospodarką i społeczeństwem 
zaczną rządzić znacznie bardziej elastyczne, pomysłowe i szybko rozwijające się grupy przestępcze.

Godny podkreślenia jest fakt, iż kongres ten był jednym z najliczniejszych $\mathrm{z}$ dotychczas zorganizowanych ${ }^{58}$. Udział polskiej delegacji (powołanej przez ministra spraw zagranicznych), niewielkiej liczebnie w porównaniu do poprzednich, uznać należy za znaczący tak w wymiarze formalnym, jak i merytorycznym $^{59}$. Warto chociażby nadmienić, iż W. Filipkowskiemu powierzono funkcję sprawozdawcy jednego z obszarów tematycznych (Committee II, agenda item 8), E.W. Pływaczewskiego wybrano zaś do składu wiceprezydentów kongresu ${ }^{60}$. Dodajmy, iż w Polsce podsumowaniem tego wydarzenia była konferencja pod hasłem „System karny i zapobieganie przestępczości”, zorganizowana przez Ośrodek Informacji ONZ w Warszawie (UNIC/Warsaw) oraz Międzynarodową Organizację ds. Migracji (IOM), która odbyła się w dniu 26 maja 2010 roku w Bibliotece Uniwersytetu Warszawskiego ${ }^{61}$.

Gospodarzem XIII Kongresu Organizacji Narodów Zjednoczony ch w sprawie zapobiegania przestępczości i sprawiedliwości karnej w 2015 ro$\mathrm{ku}^{62}$ był rząd Kataru. Jego głównym tematem było rozbudowane hasło: „Integrowanie zapobiegania przestępczości i sprawiedliwości karnej w ramach szerokiego programu działań ONZ wobec wyzwań społecznych i ekonomicznych, jak również promowanie zasady

58 Pierwotne dane (około 4000 uczestników) zostały ostatecznie skorygowane do liczby 2000, a reprezentowane były 104 oficjalne delegacje rządowe, w których występowało wielu ministrów sprawiedliwości oraz osób ze statusem ministerialnym. Uczestniczyło też 45 organizacji pozarządowych (NGO) i 17 innych podobnych jednostek.

59 Do składu oficjalnej polskiej delegacji zostali powołani: dr hab. Jacek Junosza Kisielewski — ambasador nadzwyczajny i pełnomocny RP w Federacyjnej Republice Brazylii (przewodniczący delegacji), prof. Emil W. Pływaczewski (UwB), dr Wojciech Filipkowski (UwB) oraz dr Zbigniew Rau (dyrektor Gdańskiego Parku Naukowo-Technologicznego). Ponadto na kongresie w charakterze ekspertów indywidualnych z Polski wystąpiło trzech przedstawicieli Polskiej Platformy Bezpieczeństwa Wewnętrznego (Marcin Żukowski, Rashel Talukder i Dawid Matusiak).

${ }^{60} \mathrm{Na}$ temat merytorycznego udziału polskiej delegacji — zob. B. Kunicka-Michalska, E.W. Pływaczewski, Zapobieganie przestępczości i sprawiedliwość karna (XI Kongres Organizacji Narodów Zjednoczonych, Bangkok, 18-25 IV 2005), „Państwo i Prawo” 2006, nr 2, s. 135; K. Dziedzik, Pracownicy Prawa docenieni na Kongresie ONZ w Brazylii, „Nasz Uniwersytet” 14 (21), 2010, s. 12.

${ }^{61} \mathrm{Na}$ konferencji tej w charakterze referentów wystąpili kolejno: Emil W. Pływaczewski (kierownik Katedry Prawa Karnego Uniwersytetu w Białymstoku), Janusz Rydzykowski (ambasador, Departament Narodów Zjednoczonych i Praw Człowieka MSZ), Adam Rapacki (podsekretarz stanu, MSWiA), Anna Rostocka (dyrektor Biura Międzynarodowej Organizacji ds. Migracji w Warszawie) oraz Agnieszka Wrzesień (koordynator projektu „Safer Internet”, Fundacja „Dzieci Niczyje").

$6213^{\text {th }}$ United Nations Congress on Crime Prevention and Criminal Justice. Integrating crime prevention and criminal justice into the wider United Nations agenda to address social and economic changes and to promote the rule of law at the national and international levels, and public participation. 
rządów prawa w wymiarze krajowym i międzynarodowym, także z uwzględnieniem udziału społeczeństwa"63. Konsekwencją tego było też silne akcentowanie związków pomiędzy bezpieczeństwem, sprawiedliwością i zasadą rządów prawa dla osiągnięcia lepszego, bardziej sprawiedliwego świata.

Obrady kongresu toczyły się wokół czterech głównych tematów: 1. sukcesy i wyzwania w implementacji polityki wszechstronnego (kompleksowego) zapobiegania przestępczości i wymiaru sprawiedliwości karnej oraz strategii na rzecz promowania zasady rządów prawa na płaszczyźnie krajowej i międzynarodowej oraz wspierania zrównoważonego rozwoju ${ }^{64} ; 2$. współpraca międzynarodowa, z uwzględnieniem płaszczyzny regionalnej, w zwalczaniu transgranicznej przestępczości zorganizowanej; 3. wszechstronne (kompleksowe) i zbalansowane podejścia ukierunkowane na zapobieganie i adekwatną reakcję wobec nowych i pojawiających się form transgranicznej przestępczości; 4. krajowe rozwiązania w zakresie udziału społeczeństwa $\mathrm{w}$ procesie wzmacniania zapobiegania przestępczości i sprawiedliwości karnej.

Finalnym dokumentem XIII Kongresu była Deklaracja z Dauszy (Doha Declaration $)^{65}$, której projekt — również po raz pierwszy w historii tych kongresów — został przyjęty przez aklamację już w pierwszym dniu obrad. Ten obszerny, kilkunastostronicowy dokument jest zarówno ekspozycją dotychczasowego sześćdziesięcioletniego dorobku kongresów ${ }^{66}$, uniwersalnego charakteru norm Narodów Zjednoczonych w zakresie prewencji przestępczości, jak i odpowiedzią na nowe wyzwania związane z jej rozwojem. Należy w szczególności podkreślić, iż są w niej zawarte liczne rekomendacje wskazujące, w jaki sposób zasada rządów prawa może chronić i promować zrównoważony rozwój. Wypracowane zasady organizacyjne tego dokumentu stanowią realizację założenia, iż zrównoważony rozwój i zasada rządów prawa są integralnie ze sobą związane. Zapobieganie przestępczości i sprawiedliwość karna powinny być zatem wkomponowane w szeroki system funkcjonowania Narodów Zjednoczonych. Podkreśla się także znaczenie uczciwych, humanitarnych i przewidywalnych systemów wymiaru

63 Bliżej zob. E.W. Pływaczewski, XIII Kongres Organizacji Narodów Zjednoczonych nt. „Zapobieganie przestępczości i sprawiedliwość karna” (Doha, Katar, 12-19 IV 2015 r.), „Prokuratura i Prawo" 2015, nr 11, s. 175-186.

64 Przypomnijmy, że dyrektywa, iż zapobieganie przestępczości powinno być zintegrowane z planami rozwoju społeczno-ekonomicznego, była już zresztą silnie eksponowana w czasie VII Kongresu ONZ w sprawie zapobiegania przestępczości i postępowania z przestępcami w Mediolanie.

65 A/RES/70/174, annex, para 10 (c), Doha Declaration on Integrating Crime Prevention and Criminal Justice into the Wider United Nations Agenda to Address Social and Economic Challenges and to Promote the Rule of Law at the National and International Levels, and Public Participation, 8.01.2016, https//undocs.org/A/RES/70/174 (dostęp: 15.06.2018).

66 Ze szczególnym uwzględnieniem sygnalizowanych wyżej Deklaracji z Bangkoku i Deklaracji z Salwadoru, jak również stanowiących ich kanwę licznych dokumentów w postaci konwencji, traktatów, zaleceń i rezolucji Organizacji Narodów Zjednoczonych. 
sprawiedliwości karnej oraz tworzących je instytucji jako centralnego komponentu zasady rządów prawa.

Szeroko akcentuje się wylansowaną już kilkadziesiąt lat temu ideę systemowego ujęcia wymiaru sprawiedliwości karnej, która następnie już jako dyrektywa - była twórczo rozwijana przez kolejne kongresy i szerzej znajdowała swoje przełożenie w zaleceniach i rekomendacjach ujętych w Deklaracji z Salwadoru. Zgodnie z jej założeniem poszczególne części składowe tego systemu, to jest - organy ścigania, sądownictwo (jako centralny filar struktury rządów prawa), więziennictwo, jak również programy prewencyjne (profilaktyka przestępcza), powinny funkcjonować w jego ramach jako „naczynia połączone”, a nie stanowić funkcjonujących — na ogół niezależnie obok siebie — elementów.

W „drugim nurcie” obrad kongresowych na szczególną uwagę zasługuje siedem sesji zorganizowanych przez Akademicką Radę ds. Systemu Narodów Zjednoczonych $z$ oddziałem we Wiedniu (ACUNS) ${ }^{67}$. Były one poświęcone takim zagadnieniom, jak kształcenie kolejnej generacji na rzecz sprawiedliwości w perspektywie do roku 2013, wspieranie poprzez naukowe dowody i wiarę religijną celów zrównoważonego rozwoju wypracowanych przez Zgromadzenie Ogólne ONZ na lata 2016-2030, polityczne aspekty zapobiegania przestępczości i ich efekty w zakresie obniżania poziomu przestępczości, kobiety i dzieci jako ofiary, sprawcy i występujący w roli osób zaangażowanych w zapobieganie przestępczości, koncepcje pokojowe i inkluzywne społeczeństwa na rzecz zrównoważonego rozwoju w założeniach ONZ na okres po 2015 roku oraz motywowane płcią masowe zabójstwa kobiet i dziewcząt.

Polska na omawianym kongresie reprezentowana była nad wyraz skromnie. W składzie oficjalnej polskiej delegacji pozostawał jedynie ambasador tytularny dr Janusz Rydzykowski z Ministerstwa Spraw Zagranicznych. Polskie środowisko naukowe reprezentował E.W. Pływaczewski (Uniwersytet w Białymstoku), zaproszony w charakterze eksperta indywidualnego. Warto jednak podkreślić udział Polaków w reprezentowanych na kongresie organizacjach międzynarodowych ${ }^{68}$. Sławomir Redo między innymi przedstawił dwa referaty w sesjach ACUNS I i II. Merytoryczną kanwą jednego z nich było unikalne w skali światowej jego opracowanie na temat „błękitnej kryminologii” ${ }^{69}$. Natomiast E.W. Pływaczewski

67 The Academic Council on the United Nations System - Vienna Liaison Office. Szerzej zob. „ACUNS Quarterely Newsletter” 2015, nr 1.

${ }^{68}$ Do tego grona należeli: dr hab. S. Redo - starszy ekspert Komisji ds. Zapobiegania Przestępczości i Wymiaru Sprawiedliwości ONZ (reprezentujący także ACUNS), Mirosława Czerna wydelegowana przez Międzynarodowy Komitet Czerwonego Krzyża oraz Alicja Dzuryk, doktorantka z Uniwersytetu Gdańskiego, która znalazła się w międzynarodowym składzie pięcioosobowej delegacji ELSA.

69 S. Redo, Blue Criminology. The Power of United Nations ideas to counter crime globalny. A monografic study (Ministry of Interior, Govt. of Qatar, European Institute for Crime Prevention and Control, affiliated with the United Nations; Korean Institute of Criminology, International Society for social Defence), HEUNI Publications Series No. 72, Helsinki 2012. Zob. także omówienie 
wygłosił referat w sesji ACUNS IV pod tytułem Legal and criminal justice education, the Bologna Process and the Doha Congress: Will Europe respond to its place in the post-2015 United Nations World? Godny podkreślenia jest również fakt, iż XIII Kongres był najliczniejszym z dotychczas zorganizowanych. Według danych organizatorów miało brać w nim udział około 4000 uczestników ze 159 krajów. Po skorygowaniu danych liczba uczestników spadła do 2600 osób (w tym 104 oficjalne delegacje rządowe, z których 39 miało status ministerialny).

Jak już na wstępie wzmiankowano, gospodarzem XIV Kongresu ONZ w sprawie zapobiegania przestępczości i sprawiedliwości kar$\mathrm{nej}^{70}$, przeniesionego w związku z pandemią na rok 2021, była Japonia, a jego miejscem — podobnie jak w roku 1970 - Kioto. Kongres w związku z koniecznością przestrzegania surowych reguł BHP został zorganizowany w innowacyjnym formacie hybrydowym $\mathrm{z}$ licznymi ograniczeniami pandemicznymi. $\mathrm{W}$ jego agendzie, na kanwie głównego tematu: „Postęp w zapobieganiu przestępczości, wymiarze sprawiedliwości w sprawach karnych i praworządności: w kierunku realizacji Agendy 2030", wyszczególnione zostały cztery zagadnienia tematyczne. Nawiązywały one do opracowanych przez ONZ 17 celów zrównoważonego rozwoju $^{71}$, akcentując zwłaszcza Culture of Lawfulnes i Education for Justice będące efektem Deklaracji z Dauszy. W katalogu tych zagadnień znalazły się:

- wszechstronne strategie zapobiegania przestępczości w obliczu społecznego i ekonomicznego rozwoju;

— zintegrowane podejścia w obliczu wyzwań stojących przed systemem wymiaru sprawiedliwości karnej;

- wielopłaszczyznowe strategie rządów promujące zasadę rządów prawa ${ }^{72}$, łącznie ze wspieraniem kultury prawości (zgodności z prawem) i respektowaniem kulturowych tożsamości (zgodnie z Deklaracją z Dauszy);

- współpraca międzynarodowa i pomoc techniczna ukierunkowana na zapobieganie i zwalczanie wszelkich form przestępczości, łącznie z terroryzmem we wszystkich jego formach i przejawach oraz nowymi i pojawiającymi się formami przestępczości ${ }^{73}$.

tej pracy: M. Perkowski, Omówienie pracy Stawomira Redo Blue Criminology. The Power of United Nations ideas to counter crime globalny. A monografic study, HEUNI Publications Series No. 72, Helsinki 2012, „Białostockie Studia Prawnicze” 2012, nr 12, s. 253-254.

$7014^{\text {th }}$ United Nations Congress on Crime Prevention and Criminal Justice. Advancing crime prevention, criminal justice and the rule of law; towards the achievement of the 2030 Agenda. Kyoto, Japan, 7-12 March 2021.

71 Zob. A/RES/70/1, Organizacja Narodów Zjednoczonych — Zgromadzenie Ogólne, Rezolucja przyjęta przez Zgromadzenie Ogólne w dniu 25 września 2015 roku, Przekształcamy nasz świat: Agenda na rzecz zrównoważonego rozwoju.

72 W szczególności zapewnienie dostępu do sprawiedliwości dla wszystkich, budowanie efektywnych, odpowiedzialnych, bezstronnych (obiektywnych) i włączających do życia społecznego instytucji: uwzględnienie społecznych, edukacyjnych i innych relewantnych środków.

73 Zob. E.W. Pływaczewski et al., op. cit., s. 1008-1009. 
Już na pierwszym posiedzeniu w ramach high level segment $\mathrm{w}$ dniu 7 marca 2021 roku kongres przyjął przez aklamację Deklarację z Kioto w sprawie poprawy zapobiegania przestępczości, wymiaru sprawiedliwości w sprawach karnych i praworządności: w kierunku Agendy 2030 na rzecz zrównoważonego rozwoju ${ }^{74}$. Deklaracja ta w szerokim zakresie uwzględniała zwłaszcza, sygnalizowane już, dokumenty o podobnym charakterze wypracowane na poprzednich trzech kongresach, to jest - Deklarację z Bangkoku, Deklarację z Salwadoru oraz Deklarację z Dauszy. Na posiedzeniu tym zostały również przedstawione rekomendacje przedstawicieli młodego pokolenia ukierunkowane na rozwijanie kreatywnych rozwiązań dotyczących globalnych kwestii związanych z zapobieganiem przestępczości. Wypracowano je $\mathrm{w}$ ramach poprzedzającego kongres Youth Forum ${ }^{75}$, które było kontynuacją znaczącego novum pod hasłem „The Doha Youth Forum" poprzedzającego Kongres w Dauszy w 2015 roku $^{76}$.

$\mathrm{Na}$ posiedzeniach plenarnych kongresu w Kioto, w dniach od 7 do 9 marca 2021 roku, szefowie państw lub rządów i ministrowie koncentrowali się na głównym jego temacie. Łącznie 141 urzędników wysokiego szczebla złożyło oświadczenia osobiście, online lub za pośrednictwem nagranych wcześniej prezentacji wideo. Akcentowano zwłaszcza Culture of Lawfulnes i Education for Justice będące efektem Deklaracji z Dauszy. Na dodatkową uwagę zasługuje idea „kultury prawości”, która współgra z ONZ-owską Agendą 2030 na rzecz zrównoważonego rozwoju. Na temat tej zadeklarowanej idei w „Białostockich Studiach Prawniczych" ukazało się wiele anglojęzycznych opracowań akademickich ${ }^{77}$. Ich polscy i zagraniczni autorzy podjęli ów temat z myślą o przeanalizowaniu drożności „kultury prawości” w różnych aspektach prawnych i środowiskach akademickich. Ich analizy wzbogaciły dokumentację omawianego kongresu $\mathrm{ONZ}^{78}$.

Spowodowana pandemią zmiana terminu XIV Kongresu oraz związane z tym ograniczenia i restrykcje wpłynęły znacząco na ograniczenie liczby specjalnych spotkań i wydarzeń w ramach „,drugiego nurtu” obrad, w tym zwłaszcza sesji pomocniczych (z 300 do 130). W ich organizację zaangażowanych było około 100 różnych organizacji pozarządowych, a wzięło $\mathrm{w}$ ich udział ponad 500 osób. Wszystkie spotkania pomocnicze były koordynowane z Wydziałem

74 A/CONF.2341/L.6, https://www.undoc.org/documents/commissions/CCPCJ/CCPCJ_Sesio ns/CCPJ_30/Kyoto_Declaration_V2102815.pdf (dostęp: 15.06.2018).

75 Kioto, 27-28.02.2021, z udziałem ponad 150 młodych ludzi — gimnazjalistów, studentów i świeżo upieczonych absolwentów z 30 krajów.

76 Zob. E.W. Pływaczewski, XIII Kongres..., s. 175 n.

77 Advancing Culture of Lawfulness Towards the Achievement of the 2013 Agenda, red. E.W. Pływaczewski, S. Redo, „Białostockie Studia Prawnicze. Białystok Legal Studies” 23, 2018, nr 3.

78 Zdaniem recenzentów tego specjalnego wydania „Białostockich Studiów Prawniczych” daje ono inspirację dla państw członkowskich Narodów Zjednoczonych do kontynuacji i dalszego rozwoju koncepcji kultury prawności w różnych jej aspektach, zarówno w czasie kongresu, jak i po jego zakończeniu. 
ds. Traktatowych Biura Narodów Zjednoczonych ds. Narkotyków i Przestępczości (UNODC). Wielu prelegentów podkreślało zarówno kluczową rolę bezpieczeństwa publicznego dla rozwoju społecznego oraz gospodarczego, jak i szczególne znaczenie praworządności, skutecznego zapobiegania przestępczości i współpracy międzynarodowej dla osiągnięcia celów zrównoważonego rozwoju. W zglobalizowanym i połączonym więzami międzynarodowymi świecie transgraniczny charakter przestępczości jest bowiem jednym z kluczowych wyzwań dla współczesnych państw. Działania przestępcze podważają autorytet państwa poprzez zachowania korupcyjne i szkodzą legalnym przedsięwzięciom ekonomicznym. W konsekwencji wywierają także negatywny wpływ na jakość życia obywateli, w szczególności z warstw ubogich, w tym kobiet oraz dzieci, będąc poważną przeszkodą do osiągnięcia zrównoważonego rozwoju. W wielu wystąpieniach podnoszono, że pandemia COVID-19 zwiększyła wyzwania gospodarcze i nierówności, stwarzając przy tym nowe możliwości dla rozwoju przestępczości, w tym zorganizowanej, wykorzystującej na różne sposoby trwający kryzys. Przykładem tego może być sprzedaż sfałszowanych szczepionek, przejmowanie funduszy stymulacyjnych oraz wyzysk osób, które z powodu pandemii straciły źródło utrzymania.

W związku z przypadającą na rok 202075 rocznicą funkcjonowania ONZ i piątą - przyjęcia Agendy Zrównoważonego Rozwoju 2030 zostało sfinalizowane monumentalne dzieło dedykowane Narodom Zjednoczonym, które włączono do materiałów kongresu i które stanowiło przedmiot dyskusji w czasie obrad ${ }^{79}$. Było ono efektem prac pięćdziesięcioosobowego międzynarodowego zespołu autorskiego, w tym - co wymaga szczególnego wyeksponowania - czternastoosobowego grona polskich naukowców ${ }^{80}$. Większość $\mathrm{z}$ nich wzięła również udział (w formie zdalnej) w dwóch sesjach kongresowych (nr 54 i 186).

Najliczniej na kongresie była reprezentowana Białostocka Szkoła Kryminologii $(\mathrm{BSK})^{81}$, której sześcioosobowy skład przygotował zaprezentowaną podczas sesji nr 186, zatytułowanej Crime Prevention and Justice in 2030. The UN and the Universal Declaration of Human Rights, specjalną prezentację

79 Crime Prevention and Justice in 2030. The UN and the Universal Declaration of Human Rights, red. H. Kury, S. Redo, Cham 2021.

80 Polscy autorzy reprezentowali: Uniwersytet w Białymstoku (Wydział Prawa: Anna Breczko, Wojciech Filipkowski, Ewa Guzik-Makaruk, Emilia Jurgielewicz-Delegacz, Izabela Kraśnicka, Emil W. Pływaczewski; Wydział Pedagogiki: Krzysztof Sawicki), Uniwersytet Warmińsko-Mazurski (Maciej Duda, Joanna Narodowska, Wiesław Pływaczewski), Uniwersytet Gdański (Julia Stepnowska, Kamil Zeidler), Instytut Justologii (Karol Rutkowski) oraz United Nations Studies Association (Sławomir Redo — jako współredaktor i współautor).

81 Szerzej zob. E.W. Pływaczewski, E.M. Guzik-Makaruk, W. Filipkowski, Teoria i praktyka - inicjatywy i prace badawcze Białostockiej Szkoły Kryminologii, „Państwo i Prawo” 2019, nr 3, s. 96-116; eidem, The Biatystok School of Criminology (BSC), "The Criminologist” 44, 03-04.2019, nr 2, s. 48-49. 
multimedialną ${ }^{82}$. Natomiast podczas sesji $\mathrm{nr} 54$ pod tytułem Teaching the UN Sustainable Development Criminology została wyeksponowana recenzja wcześniejszej, związanej z tematyką kongresu, monografii ${ }^{83}$. Niezależnie od tego BSK była bezpośrednio reprezentowana na kongresie przez mgr Martę Dzieniszewską z Katedry Prawa Karnego i Kryminologii UwB, jedynego przedstawiciela z Polski uczestniczącego „na miejscu” w obradach kongresowych.

Z wyliczeń statystycznych wynika, że w kongresie wzięło udział ponad 5000 uczestników (ponad $4000 \mathrm{z}$ nich zostało zarejestrowanych do udziału online) reprezentujących 152 kraje członkowskie, 114 organizacji pozarządowych i 17 organizacji międzyrządowych. Ustanowiony więc został nowy rekord uczestnictwa, na który niewątpliwie miała wpływ przyjęta przez organizatorów hybrydowa formuła jego przebiegu.

\section{Próba podsumowania}

Kongresy ONZ w sprawie zapobiegania przestępczości i sprawiedliwości karnej (postępowania z przestępcami) od wielu już lat gromadzą decydentów, wybitnych przedstawicieli środowisk akademickich oraz praktyków reprezentujących organy ścigania i wymiaru sprawiedliwości, organizacje międzyrządowe i społeczeństwo obywatelskie. Gremium to czyni wysiłki, nie zawsze jednak skuteczne, na rzecz wzmocnienia międzynarodowej współpracy w zakresie zapobiegania przestępczości i określania nowych zasad dla przyszłej działalności uwzględniającej zmiany w strukturze ekonomicznej i społecznej w mikro- i makroskali oraz ich wpływ na wymiar sprawiedliwości.

Omawiane kongresy ONZ przez kilkadziesiąt lat stanowiły nie tylko forum wymiany poglądów czy prezentacji dorobku poszczególnych państw, lecz wypracowywały dokumenty o dużym, a niekiedy fundamentalnym, znaczeniu dla wielu systemów prawnych, poczynając od reguł minimalnych postępowania z więźniami, a kończąc - na Deklaracji z Kioto ustanowionej na XIV Kongresie, określającej zintegrowane podejście do wyzwań związanych z przeciwdziałaniem przestępczości na świecie w nowych uwarunkowaniach społecznych oraz ustrojowych.

Deklaracja ta — jak już wskazywano - jest zarówno ekspozycją dotychczasowego dorobku kongresów w sprawie zapobiegania przestępczości i sprawiedliwości karnej (postępowania z przestępcami) - zwłaszcza XI, XII i XIII, uniwersalnego charakteru norm Narodów Zjednoczonych w zakresie prewencji przestępczości, łącznie z reakcją na działania o znamionach totalitaryzmu

82 Zob. E.W. Pływaczewski, E. M. Guzik-Makaruk, W. Filipkowski, E. Jurgielewicz-Delegacz, E.M. Truskolaska, A. Stachelska, From Wonders as Crime to Crime Prevention - Inspired Culture of Lawfulness in Digital Age: Perspective from Biatystok School of Criminology (Poland).

${ }^{83}$ Zob. E.W. Pływaczewski, Review of „Helmut Kury, Stawomir Redo (eds.), Refugees and Migrants in Law and Policy. Challenges and Opportunities for Global Civic Education, Cham 2018, pp. 913”, „Studia Iuridica Lubliniensia” 29, 2020, nr 5, s. 365-367. 
i ekstremizmu. Stanowi również odpowiedź na nowe wyzwania związane z przedłużającym się kryzysem, rozwojem przestępczości i innych patologii społecznych. Zawarte w Deklaracji z Kioto liczne rekomendacje wskazują, w jaki sposób system rządów prawa może wzmocnić zapobieganie przestępczości i wymiar sprawiedliwości w sprawach karnych, chronić i promować zrównoważony rozwój, a w konsekwencji — stanowić istotną gwarancję osiągnięcia celów Agendy Zrównoważonego Rozwoju 2030.

W tym przekrojowym kontekście dorobek dotychczasowych kongresów jest imponujący. Wywierały i nadal wywierają one na ogół istotny wpływ na kierunki działań poszczególnych państw i stosowaną w nich praktykę organów ścigania oraz wymiaru sprawiedliwości. Kongresy umożliwiały też dzielenie się interesującymi doświadczeniami na forum międzynarodowym oraz wymianę informacji pomiędzy krajami i przedstawicielami określonych grup zawodowych. Tym samym na płaszczyźnie współczesnej ochrony podstawowych praw człowieka stworzono możliwość promowania bardziej efektywnych sposobów przeciwdziałania przestępczości i innym patologiom społecznym zarówno w obszarze funkcjonowania organów ścigania i wymiaru sprawiedliwości, jak i w szeroko rozumianej profilaktyce kryminologicznej. Osiągnięcie celów zrównoważonego rozwoju nie będzie jednak możliwe bez globalnej współpracy w zakresie zapobiegania i zwalczania przestępczości, zdecydowanej reakcji na łamanie praw człowieka i podjęcia skutecznych działań na rzecz wyjścia z pandemii.

W nawiązaniu do wątku - niewątpliwie znaczącego - ,polskiego wkładu" w dorobek omawianej kategorii kongresów wypadałoby również odnotować szczególne zaangażowanie, tak w wymiarze merytorycznym, jak i organizacyjnym, powoływanego wyżej dr hab. Sławomira Redy, który będąc pracownikiem Biura ONZ ds. Narkotyków i Przestępczości w latach 1981-2011, współuczestniczył w przygotowaniu i organizacji kolejnych kongresów. Był on ponadto współorganizatorem i wykonawcą szeregu ONZ-owskich projektów poświęconych przeciwdziałaniu przestępczości zorganizowanej na świecie, gwarancji niezawisłości sędziowskiej, przestępczości komputerowej, problematyki stosowania i zniesienia kary śmierci, trendów przestępczości na świecie, wdrażania ONZ-owskich norm i standardów dla ofiar przestępstw, humanitarnego i skutecznego postępowania wobec ich sprawców, zapobiegania przestępczości miejskiej, funkcjonowania prywatnej policji oraz prewencji kryminalnej na Globalnym Południu. Ponadto brał udział w tworzeniu przełomowej dla Biura ONZ Konwencji Narodów Zjednoczonych przeciwko międzynarodowej przestępczości zorganizowanej, Forum Przestępczości Cybernetycznej oraz e-learningu: kształcenia studentów w zakresie ONZ-owskich norm i standardów przeciwdziałania przestępczości. Od wielu lat współpracuje też z Białostocką Szkołą Kryminologii, będąc między innymi współautorem (cytowanego w przypisie 5) najnowszego akademickiego podręcznika kryminologii uwzględniającego założenia Agendy ONZ na rzecz zrównoważonego rozwoju 2030. 


\section{Bibliografia}

„ACUNS Quarterely Newsletter” 2015, nr 1.

Advancing Culture of Lawfulness Towards the Achievement of the 2013 Agenda, red. E.W. Pływaczewski, S. Redo, „Białostockie Studia Prawnicze. Białystok Legal Studies” 23, 2018, nr 3.

Bieńkowska E., Wiktymologia, Warszawa 2018.

Crime Control in Poland. Polish Report for the Ninth United Nations Congress on the Prevention of Crime and the Treatment of Offenders (Cairo, Egypt, 29 April-8 Mai 1995), red. J. Jasiński, A. Siemaszko, Warszawa 1995.

Crime Prevention and Justice in 2030. The UN and the Universal Declaration of Human Rights, red. H. Kury, S. Redo, Cham 2021.

Dziedzik K., Pracownicy Prawa docenieni na Kongresie ONZ w Brazylii, „Nasz Uniwersytet” 14 (21), 2010.

Filar M., Criminal Justice Police in the Crossnational Perspective, Torun 1991.

Filar M., Przestępczość i jej zapobieganie warunkach wdrażania nowego międzynarodowego ładu gospodarczego (z perspektywy europejskich państw socjalistycznych), [w:] Problematyka przestępczości na VII Kongresie Narodów Zjednoczonych, Mediolan, 26 sierpnia - 6 września 1985, red. B. Hołyst, Warszawa 1977.

For the Rule of Law: Criminal Justice Teaching and Training @ Cross the World. HEUNI, red. K. Aromaa, S. Redo, Helsinki-Seoul 2008.

Gomuła J., Sympozjum z okazji 50-lecia Organizacji Narodów Zjednoczonych (INP PAN, 12 IX 1995), „Państwo i Prawo” 1996, nr 5.

Górny J., Rola międzynarodowych kongresów penitencjarnych w rozwoju teorii i praktyki wykonania kary, Warszawa 1980.

Hołyst B., V Kongres Narodów Zjednoczonych w sprawie Zapobiegania Przestępczości i Postępowania z Przestęcami, „Państwo i Prawo” 1976, nr 1-2.

Hołyst B., Kryminologia. Podstawowe problemy, Warszawa 1977.

Hołyst B., Sprawozdanie z VII Kongresu Narodów Zjednoczonych w Sprawach Zapobiegania Przestepczości i Postepowania ze Sprawcami (Mediolan 26 sierpnia - 6 września 1985), „Problemy Praworządności” 1985, nr 11.

Krzan B., Kompetencje Rady Bezpieczeństwa ONZ w międzynarodowym sądownictwie karnym, Toruń 2007.

Kunicka-Michalska B., VIII Kongres ONZ w sprawie zapobiegania przestępczości i postępowania z przestęcami (Hawana, 27 VIII - 7 IX 1990), „Państwo i Prawo” 1991, nr 8.

Kunicka-Michalska B., Pływaczewski W., Zapobieganie przestępczości i sprawiedliwość karna (XI Kongres Organizacji Narodów Zjednoczonych, Bangkok, $18-25$ IV 2005), „Państwo i Prawo" 2006, nr 2.

Maćkowiak P., Zagadnienie tortur, [w:] Problematyka przestępczości na V Kongresie Narodów Zjednoczonych, Genewa, wrzesień 1975, red. B. Hołyst, Warszawa 1976.

Marek A., Gtówne tendencje polityki kryminalnej na forum ONZ a reforma polskiego prawa karnego, „Państwo i Prawo” 1983, nr 1.

Od redakcji, [w:] Problematyka przestępczości na VI Kongresie Narodów Zjednoczonych, Caracas, 25 sierpnia - 5 września 1980, red. B. Hołyst, Warszawa 1983.

Od redakcji, [w:] Problematyka przestępczości na VII Kongresie Narodów Zjednoczonych, Mediolan, 26 sierpnia - 6 września 1985, red. B. Hołyst, Warszawa 1977.

Perkowski M., Omówienie pracy Stawomira Redo Blue Criminology. The Power of United Nations ideas to counter crime globalny. A monografic study, HEUNI Publications Series No. 72, Helsinki 2012, „Białostockie Studia Prawnicze” 2012, nr 12. 
Pływaczewski E.W., XII Kongres Organizacji Narodów Zjednoczonych (Salwador, Brazylia, 12-19 IV 2010), „Państwo i Prawo” 2010, nr 10.

Pływaczewski E.W., XIII Kongres Organizacji Narodów Zjednoczonych nt. „Zapobieganie przestępczości i sprawiedliwość karna” (Doha, Katar, 12-19 IV 2015 r.), „Prokuratura i Prawo” 2015 , $\mathrm{nr} 1$.

Pływaczewski E.W., Komunikat z Kongresu Organizacji Narodów Zjednoczonych w Kairze, „Przegląd Policyjny" 1996, nr 11.

Pływaczewski E.W. (red.), Przestępczość zorganizowana, Warszawa 2011.

Pływaczewski E.W., Review of ,,Helmut Kury, Stawomir Redo (eds.), Refugees and Migrants in Law and Policy. Challenges and Opportunities for Global Civic Education, Cham 2018, pp. 913", „Studia Iuridica Lubliniensia” 29, 2020, nr 5.

Pływaczewski E.W., Guzik-Makaruk E.M., Filipkowski W., Teoria i praktyka - inicjatywy i prace badawcze Białostockiej Szkoły Kryminologii, „Państwo i Prawo” 2019, nr 3.

Pływaczewski E.W., Filipkowski W., Guzik-Makaruk E.M., The Białystok School of Criminology (BSC), „The Criminologist” 44, 03-04.2019, $\mathrm{nr} 2$.

Pływaczewski E.W., Redo S., Guzik-Makaruk E.M., Laskowska K., Filipkowski W., Glińska E., Jurgielewicz-Delegacz E., Perkowska M., Kryminologia. Stan i perspektywy rozwoju. Z uwzględnieniem Agendy ONZ na rzecz zrównoważonego rozwoju 2030, Warszawa 2019.

Problematyka przestępczości na V Kongresie Narodów Zjednoczonych, Genewa, wrzesień 1975, red. B. Hołyst, Warszawa 1976.

Redo S., Blue Criminology. The Power of United Nations ideas to counter crime globalny. A monografic study (Ministry of Interior, Govt. of Qatar, European Institute for Crime Prevention and Control, affiliated with the United Nations; Korean Institute of Criminology, International Society for social Defence), HEUNI Publications Series No. 72, Helsinki 2012.

Redo S., Międzynarodowe zasady zapobiegania przestępczości, „Przegląd Policyjny” 2009, nr 2.

Redo S., Zwalczanie przestępczości zorganizowanej w Azji Centralnej, Warszawa 2007.

Refugees and Migrants in Law and Policy. Challenges and Opportunities for Global Civic Education, red. H. Kury, S. Redo, Cham 2018.

Skupiński J., Konwencja ONZ z 10 XII 1984 r. przeciwko torturom oraz innym formom nieludzkiego traktowania, „Państwo i Prawo” 1986, nr 11.

Smoleński J., IV Kongres ONZ w sprawie zapobiegania przestępczości i zapobiegania przestępca$m i$, ,Problemy Praworządności” 1970, nr 11-12.

The Institute of Crime Problems. Research Institute on Judicial Law, Sixth United Nations Congress on the Prevention on Crime and the Treatment on Offenders. Caracas, 25 August - 5 September 1980, red. B. Hołyst, Warszawa 1980.

Tomczyk W., Głos w dyskusji, [w:] ONZ a zwalczanie przestępczości, „Gazeta Prawnicza” 15 (508), 1.08.1985.

Walczak S., Wspótczesne tendencje $w$ dziedzinie pracy penitencjarnej i zwalczania przestępczości. Refleksje w zwiazku z II Kongresem ONZ w sprawie zapobiegania przestępczości i postępowania z przestępcami, „Państwo i Prawo” 1961, nr 4-5.

Walczak S., Wywiad, „Służba Penitencjarna” 1965, nr 9.

Węgrzyn J., Struktury Organizacji Narodów Zjednoczonych zajmujące się problematyka przestępczości, „Nowe Prawo” 1991, nr 4-6.

Zielińska E., Jasiński J., Poklewski-Koziełł K., Zapobieganie przestępczości i postepowanie z przestępcami (IX Kongres NZ, Kair, 29 IV - 8 V 1995), „Państwo i Prawo” 1995, nr 8. 


\section{Źródła}

A/55/59, The Vienna Declaration on Crime and Justice: Meeting the Challenges of the Twenty-first Century.

A/60/177, The Bangkok Declaration - Synergies and Responses: Strategic Alliances in Crime Prevention and Criminal Justice.

A/CONF.2341/L.6,https://www.undoc.org/documents/commissions/CCPCJ/CCPCJ_Sesions/CCPJ 30/Kyoto_Declaration_V2102815.pdf.

A/RES/70/1, Organizacja Narodów Zjednoczonych — Zgromadzenie Ogólne, Rezolucja przyjęta przez Zgromadzenie Ogólne w dniu 25 września 2015 roku, Przekształcamy nasz świat: Agenda na rzecz zrównoważonego rozwoju.

A/RES/70/174, annex, para 10 (c), Doha Declaration on Integrating Crime Prevention and Criminal Justice into the Wider United Nations Agenda to Address Social and Economic Challenges and to Promote the Rule of Law at the National and International Levels, and Public Participation, 8.01.20016, https//undocs.org/A/RES/70/174.

Pakty Praw Obywatelskich i Politycznych z 16 grudnia 1966 roku.

Porozumienie międzynarodowe w przedmiocie ścigania i karania głównych przestępców wojennych Osi Europejskiej z dnia 8 lipca 1945 roku (Dz.U. z 1947 r. Nr 63, poz. 367).

Powszechna Deklaracja Praw Człowieka z 10 grudnia 1948 roku.

Rezolucja 95 (I) Zgromadzenia Ogólnego Narodów Zjednoczonych z dnia 11 lipca 1946 roku.

Wyrok Trybunału Norymberskiego z 30 września - 1 października 1946 roku. 